\title{
THE FOX AND THE OSTRICH: IS GAAP A GAME OF WINKS AND NODS?
}

\author{
ARTHur ACEVEDo ${ }^{1}$ \\ It has been observed "that accountants \\ 'are quite prone to define 'generally accepted' as 'somebody tried it."'”2
}

I. INTRODUCTION

II. ECONOMIC TRIFECTA OR BERMUdA TRIANGLE?

A. Flexible Accounting Standards

B. Management Discretion

C. Judicial Deference

III. The Regulatory Framework of Accounting Rules
A. British Influence
B. Interstate Commerce Commission
C. Federal Securities Acts
D. Administrative Guidance

\footnotetext{
1 Arthur Acevedo is an Assistant Professor of Law at the John Marshall Law School in Chicago, Illinois. He received his Juris Doctor, Master of Science in Taxation, and Baccalaureate Science in Commerce degrees from DePaul University. He also received his certificate as a Certified Public Accountant in Illinois. The author is grateful to Professor Jason Kilborn for his valuable assistance throughout the various revisions. The author also wishes to thank his research assistants Oksana Koltko and Young-Joo (Ashley) Ahn. Finally, the author wishes to thank Patricia Mendoza for her comments and tireless efforts in reading through numerous revisions.

2 Thor Power Tool Co. v. Comm'r, 439 U.S. 522, 544 n.22 (1979) (quoting Arthur M. Cannon, Tax Pressures on Accounting Principles and Accountants' Independence, 27 AсCT. REV. 419, 421 (1952)).
} 


\section{E. Diverging from Congressional Policy?}

IV. GOVERnMent or Private Standard Setter?
A. SEC Structure
B. History of Private Standard Setters
C. What is the Public Interest?

V. GAAP'S INFLUENCE ON THE LAW
A. Federal Level Influence
B. State Level Influence
C. Instances of Cases Accepting GAAP
D. Instances of Cases Rejecting GAAP
E. Instances of Private Party Reliance on GAAP

VI. CONCLUSION

"In a national survey of chief financial officers . . 62 percent believe it would be possible to intentionally misstate their [company's] financial statement to their auditor." Whether this statistic represents the ego or experience of chief financial officers or both, it is alarming given the fact that the Securities and Exchange Commission ("SEC") turns to the accounting profession for help in creating the very accounting standards used by accountants and auditors when preparing and auditing financial statements. ${ }^{4}$ If chief financial officers believe they can mislead auditors, what prevents them from misleading investors?

\footnotetext{
3 The following question was asked in a national survey conducted by Grant Thornton in 2007: "Do you believe it would be possible to intentionally misstate your financial statement to your auditor?" 62.44\% responded "yes" and 37.10\% responded "no." See Grant Thorton, Nearly Two Thirds of CFOs Feel They Could Intentionally Misstate Financial Statements; Only Half Aware of XBRL, Nov. 7, 2007, http://www.grantthornton.com/portal/site/gtcom/menuitem.550794734a67d883a5f2ba40633841ca /?vgnextoid=e43a105b46016110VgnVCM1000003a8314acRCRD\&vgnextchannel $=$ a44ecbbdad9c401 0VgnVCM100000368314acRCRD.

4 See generally Lawrence A. Cunningham, Private Standards in Public Law: Copyright, Lawmaking and the Case of Accounting, 104 MicH. L. REV. 291, 292-93 (2005).
} 
Congress expressly granted to the SEC the authority to enact rules to regulate accounting standards. ${ }^{5}$ However, the SEC defers to private standard setters ${ }^{6}$ to create and regulate the accounting standards commonly known as Generally Accepted Accounting Principles (“GAAP”). ${ }^{7}$ This article examines the SEC's failure to create and actively regulate accounting standards. ${ }^{8}$

The SEC's practice of deferring to private standard setters is irresponsible. The failure to act has created public confusion and allowed companies to manipulate financial results. Despite an unenforceable statement of public duty, private standard setters bear no responsibility to the public and, therefore, are free to advocate for the commercial interests of their members and their clients, all at great public expense. ${ }^{9}$

\begin{abstract}
515 U.S.C. $\int 77 \mathrm{~s}(\mathrm{~b})$ states in relevant part that "[i]n carrying out its authority under subsection (a) and under section $78 \mathrm{~m}$ (b) of [the Securities Exchange Act of 1934], the [SEC] may recognize, as 'generally accepted' for purposes of the securities laws, any accounting principles established by a standard setting body ... (A) that-- (i) is organized as a private entity; (ii) has . . . a board of trustees serving in the public interest . . [ [ and] (iv) has adopted procedures to ensure prompt consideration . . of changes to accounting principles." 15 U.S.C. $\int 77 \mathrm{~s}(\mathrm{~b})(2006)$.

${ }^{6}$ For purposes of this article, the term "private standard setters" includes the Financial Accounting Standards Board ("FASB") and its predecessor organizations, the Committee on Accounting Procedure ("CAP"), the Accounting Principles Board ("APB"), and any successor organization including the International Accounting Standards Board ("IASB"). The SEC is studying the possibility of requiring U.S. issuers to adopt International Financial Reporting Standards ("IFRS") in lieu of GAAP in 2011. If adopted, IFRS would be created by yet another private standard setter, the International Accounting Standards Board ("IASB"). See 73 Fed. Reg. 70820 (Nov. 21, 2008). The IASB has even less incentive than the FASB to protect the interests of U.S. investors.
\end{abstract}

7 'The phrase 'generally accepted accounting principles' is a technical accounting term that encompasses the convention, rules, and procedures necessary to define accepted accounting practice at a particular time. It includes not only broad guidelines of general application, but also detailed practices and procedures. Those conventions, rules, and procedures provide a standard by which to measure financial presentations." AUDITING STANDARDS BOARD, AMERICAN INSTITUTE OF Certified Public Accountants, The Meaning of Present Fairly in Conformity with Generally Accepted Accounting Principles, in AU $\int 411$, at 570 (1992), available at http://pcaobus.org/standards/auditing/pages/au411.aspx. See also Cunningham, supra note 4, at 293.

8 Cunningham, supra note 4, at 293.

9 "The mission of the FASB is to establish and improve standards of financial accounting and reporting that foster financial reporting by nongovernmental entities that provides decision-useful information to investors and other users of financial reports." See Financial Accounting Standards Board, Facts about FASB, http://www.fasb.org/facts/index.shtml\#mission (last visited Sep. 23, 2010). 
Part I of this article briefly chronicles the consequence of unregulated financial activity. Part II examines the convergence of three distinct doctrines: flexible accounting standards, management discretion and judicial deference, and their collective impact on our jurisprudence. Part III analyzes the creation of accounting principles. Part IV examines the history and organizational structures of the accounting profession, as well as the SEC, and evaluates whether government is a better standard setter. Part V explores GAAP's influence and impact on American courts. Specifically, Part V examines instances where GAAP has been accepted and rejected by courts when resolving a dispute among litigants. Finally, Part VI proposes that the federal government take on an active and primary role in establishing accounting standards which are clear, consistent, and conservative that narrow the range of differences and are reasonably expected and understood by the average investor.

\section{INTRODUCTION}

The absence of financial regulation and its hazards on society is apparent when examining economic history. Early examples include the Tulipomania craze in Holland ${ }^{10}$ and the South-Sea Company incident in England. ${ }^{11}$ Both events reveal the psychology and perils of uninformed mass speculation by investors. ${ }^{12}$ The South-Sea Company incident highlights the consequences of groundless mass speculation that

10 The Tulipomania craze describes an incident of speculative trading in tulip bulbs during the seventeenth century. The tulip was imported into the Netherlands from Turkey as a symbol of wealth and status. A market in tulip trading developed, and investors and speculators entered into contracts to buy and sell tulip bulbs. Many individuals initially profited as the demand and price for tulips increased. However, the price and demand for tulips collapsed in 1637, when buyers would not buy the tulips at the higher prices. In anticipation of a price ceiling, the market price collapsed, leaving many individuals in financial distress as their contract price far exceeded the value of the underlying tulip bulb. See generally Charles Mackay, Extraordinary Popular Delusions and the MADNESS OF CROWDS 89 (L.C. Page \& Co. 1963) (1841).

11 England granted the South Sea Company an exclusive right to exploit trading opportunities in South America. In exchange for the trading rights, the South Sea Company agreed to assume a portion of England's national debt. Public speculation in the activities of the South Sea Company fueled in part by the participation of government officials caused the price of the company's stock to grow from $£, 100$ to almost $£, 1000$ in the course of one year, only to settle back to a price level near $f_{100}$. The dramatic rise and fall of the stock price resulted in numerous losses and bankruptcies for investors. See id. at 46.

${ }^{12} I d$. at 46,89 . 
can easily occur in an unregulated market. ${ }^{13}$ The British Parliament enacted the South Sea Bubble Act ("Bubble Act") in response to the abuses the marketplace exacted on investors. ${ }^{14}$ The Bubble Act prohibited the incorporation of companies unless they were authorized by the British government. ${ }^{15}$

The consequence of an unregulated financial market is evident when examining the stock market crash of 1929. ${ }^{16}$ Responding to abusive practices in the capital markets, Congress enacted the Securities Act of 1933 ("Securities Act") ${ }^{17}$ and the Securities Exchange Act of 1934 ("Exchange Act"). ${ }^{18}$ Nearly seventy years later, beginning in 2001, the United States economy once again experienced the collapse of the financial markets as companies began to issue accounting restatements. ${ }^{19}$ Investors were left wondering how so many accounting restatements could occur. In

\footnotetext{
${ }^{13} I d$. at 46.

${ }^{14}$ The South Sea Bubble Act, 1719, 6 Geo. I, c. 18 (Eng.).

${ }^{15} \mathrm{Id}$.
}

16 "During the speculative orgy of 1928 and 1929, stock-exchange authorities made no adequate effort to curb activities on their exchanges. On the contrary, they conceived it as no part of their function to discourage excessive speculation or to warn the public that security values were unduly inflated." S. ReP. No. 1455, at 81 (1934), reprinted in Federal SECurities Laws; Legislative History 1933 1982, at 1344 (1983). See also James Harlan Koenig, The Basics of Disclosure: The Market for Information in the Market for Corporate Control, 43 U. MiAmi L. REV. 1021, 1025 (1989) ("Prior to the 1933 Act and during the stock market crash of 1929, investors generally purchased securities under the philosophy of caveat emptor.").

17 Securities Act of 1933, ch. 38, 48 Stat. 74 (codified as amended at 15 U.S.C. \$S 77a-77aa (2006)).

18 Securities Exchange Act of 1934, ch. 404, 48 Stat. 881 (codified as amended at 15 U.S.C. IS 78 a78pp (2006)).

19 "A financial statement restatement occurs when a company, either voluntarily or prompted by auditors or regulators, revises public financial information that was previously reported." U.S. Senate, U. S. Gen. Accounting Office, Report to the Chairman, Committee on Banking, Housing, \& URban AFFAirs 1 n.1 (OCT. 2002).

From January 1997 through June 2002, about 10 percent of all listed companies announced at least one restatement. Among the restating companies ... identified, the number of large company restatements had grown rapidly since 1997. The average (median) size by market capitalization of a restating company increased from $\$ 500$ million . . . in 1997 to $\$ 2$ billion . . in 2002 . . [ [t is estimated] that the restating companies lost about $\$ 100$ billion in market capitalization.

Id. at 4,5 . 
response to the shaken investor confidence in the capital markets in general and in the accounting industry in particular, Congress enacted the Sarbanes Oxley Act in 2002 ("SOX") in an attempt to stem the decline in investor confidence. ${ }^{20}$ The common denominator in all of these market crashes is that they operated in an unregulated environment.

Amazingly, episodes of financial ruin keep repeating themselves. A pattern of "boom, bubble, and burst" is imprinted on the pages of financial history. ${ }^{21}$ There are three possible explanations for the repeated incidents of financial adversity. First, the enactment of financial reforms provides a false sense of security. ${ }^{22}$ Individual investors may reenter the market following a market reform under the mistaken impression that the enacted legislation is prophylactic in scope and therefore addresses all abusive practices. ${ }^{23}$ Second, knowledge of the financial adversity is private and localized, and therefore, complete information of the event is not fully disclosed. ${ }^{24}$ Third, the government fails to act.

The SEC has recognized the importance and significance of sound financial reporting by stating that a "[c]omplete and accurate financial reporting by public companies is of paramount importance to the disclosure system underlying the stability and efficient operation of our capital markets." ${ }^{25}$ Joining the SEC, the Accounting Principles Board ("APB") noted that "[a]ccounting is essential to the effective functioning of any business organization, particularly the corporate form." 26

\footnotetext{
20 See Sarbanes-Oxley Act of 2002, Pub. L. No. 107-204, 116 Stat. 745 (enacted July 30, 2002).

21 Lawrance L. Evans JR., Why the Bubble Burst: US Stock Market Performance Since 1982204 (Malcolm C. Sawyer ed. 2003).

22 See James D. Cox et al., Securities Regulation: Cases and Materials 6 (6th ed. 2009).

23 The federal securities laws are a perfect example of a piecemeal approach to securities regulation. "There is an important difference in style between the Securities Act and the Exchange Act. In the Securities Act, Congress empowered the Federal Trade Commission (FTC) to discharge a specific and well-defined task: the registration of [initial] public offerings of securities not otherwise exempt from the Act." Id. However, the Exchange Act is designed to address problems investors encounter with public securities after the initial registration process has been completed. See id.

24 See id.

25 Request for Comment on Increasing the Level of Involvement of the Independent Accountant, 54 Fed. Reg. 27023, 27024 (June 27, 1989) (codified at 17 C.F.R. pts. 210, 230 \& 240).

26 American Institute of Public Accountants, Committee on Accounting Procedure, Accounting Research Bulletin No. 43, at 6005 (1953). Accounting principles apply equally to
} 
The APB further stated that "[t] he test of the corporate system ... ultimately lies in the results which are produced. These results must be judged from the standpoint of society as a whole-not merely from that of any one group of interested persons." ${ }^{27}$ Sound financial reporting presumes sound accounting standards.

Yet, for all of its social and economic importance, establishing accounting standards has been the subject of limited federal, and virtually no meaningful state regulation. $^{28}$ Several reasons explain this phenomenon. First, the accounting profession adamantly resists government regulation and has been successful, until recently. ${ }^{29}$ Second, scarce government resources have not been sufficiently allocated to handle the ever-increasing complexity of accounting issues. ${ }^{30}$ Third, the deferential posture adopted by both legislators and courts has created within the accounting profession, a culture of entitled noninterference. Finally, a common misperception exists among many individuals, including lawyers and politicians, that accounting is a rudimentary number-crunching exercise. ${ }^{31}$

Rather than actively generating accounting standards, the SEC has consistently followed a policy, since its inception, of allowing private standard setters to establish accounting standards. ${ }^{32}$ The failure by the SEC to actively create GAAP

all forms of business entities from a sole proprietor to a multinational company. For purposes of this article, the corporate form is used throughout for ease of reference.

${ }^{27} \mathrm{Id}$.

28 See generally Cristina M. DeCelestino, Krispy Kreme, Sarbanes-Oxley, and Corporate Greed, 15 U. Miami Bus. L. REV. 225, 241 (2007).

${ }^{29}$ SOX regulates the accounting profession. Before SOX, the accounting industry was self-regulated. See Sarbanes-Oxley Act of 2002, Pub. L. No. 107-204, 116 Stat. 745 (enacted July 30, 2002).

30 The budget request for FY 2009 and FY 2008 was $\$ 913$ and $\$ 906$ million respectively, a less than 1\% increase from FY 2008 to FY 2009. See Securities and Exchange Commission, Fy 2009 CONGRESSIONAL JUSTIFICATION IN BRIEF 7 (2008). “The budget request for FY 2010 totals $\$ 1.026$ billion, a $\$ 66$ million (7 percent) increase over the agency's FY 2009 funding level of $\$ 960$ million.” See Securities and Exchange Commission, Fy 2010 Congressional Justification in Brief 7 (2009), available at http://www.sec.gov/about/secfy10congbudgjust.pdf.

31 Contrary to popular belief, accounting is not about number crunching, it also has very little to do with counting beans.

32 See Jacob L. Barney, Beyond Economics: The U.S. Recognition of International Financial Reporting Standards as an International Subdelegation of the SEC's Rulemaking Authority, 42 VAND. J. TRANSNAT'L L. 579, 599 (2009). 
generates accounting standards that are confusing, inconsistent, and at times, incomprehensible. ${ }^{33}$ Conflicting levels of accounting authority among the accounting standards issued by private standard setters add to an atmosphere of complexity and confusion. ${ }^{34}$ Moreover, private standard setters are not immune to the pressures of capitalism and, therefore, may respond in ways that are not in the best interests of transparent financial reporting. ${ }^{35}$

Accounting standards influence how and what financial results are reported to users of financial statements. ${ }^{36}$ They are used to identify, record, and report the financial events of an entity. ${ }^{37}$ They also have an immediate and direct influence on a company, its shareholders, and, ultimately, our society. ${ }^{38}$ Additionally, they are determinative in measuring rights and responsibilities and are frequently at the center

33 The Supreme Court notes that " $[t]$ here are 19 different GAAP sources, any number of which might present conflicting treatments of a particular accounting question. When such conflicts arise, the accountant is directed to consult an elaborate hierarchy of GAAP sources to determine which treatment to follow.” Shalala v. Guernsey Mem’l Hosp., 514 U.S. 87, 101 (1995).

34 See Guar. Mortgage Co. v. Flint, 240 P. 175, 185 (Utah 1925) ("Financial statements of [banks] and of other similar corporations, as usually put out, with a classification and transposition of denominated assets of self-serving values and of stated liabilities, and of items of discount and surplus of variant meanings operated like a shuttlecock between them, generally do not mean much to the ordinary person ... and often are understood only by accountants or by those having knowledge of methods and terms of accounting, and when understood frequently are not what they seem.”).

35 Throughout the 1980s and 1990s, when the use of stock options swelled, a furious debate developed concerning whether companies should reflect the current cost of stock options in their financial statements or defer the cost until a later point in time when the option was exercised. Clear and definitive guidance was slow in coming. Companies are now permitted to follow either APB 25 (intrinsic value method) or FAS 123 (fair value method) when accounting for stock option costs. The Department of Commerce noted in discussing the alternative treatments for stock option accounting that the "accounting rules for financial statements result in an understatement of compensation costs and a corresponding overstatement of profits." CAROL MOYLAN, BUREAU OF ECONOMIC ANALYSIS, U.S. Dep't of Commerce, Treatment of Employee Stock Options in the U.S. National ECONOMIC ACCOUNTS 2, available at http://www.bea.gov/papers/pdf/empstop.pdf (last visited Aug. 12, 2010).

36 See Financial Accounting Standards Board, Statement of Financial Accounting CONCEPTS NO. 1, at 13-14 (1978).

${ }^{37} I d$. at 5.

${ }^{38} I d$. at 15. 
of debate between litigants. ${ }^{39}$ Therefore, accounting standards function much like our laws and touch many aspects of our lives. They influence federal and state legislation; they impact the public and private sectors of the economy; and they affect many individual and corporate transactions. Furthermore, the importance of accounting standards is seen in the courts. One court even remarked that "[ $[$ the 'single unified purpose' of GAAP is 'to increase investor confidence by ensuring transparency and accuracy in financial reporting."” 40

History has shown that financial disasters can be placed into three broad categories: financial fraud ${ }^{41}$ groundless mass speculation, ${ }^{42}$ and incessant individual greed. ${ }^{43}$ The impact of these three categories, while personally devastating to the

39 See Automodular Assemblies, Inc. v. PNC Bank, No. Civ.A. 19352, 2004 WL 1859828, at*1 (Del. Ch. 2004) ("F]inancial statements were the basis for measuring . . compliance with certain financial covenants.”).

40 In re Worldcom, Inc. Sec. Litig., 352 F. Supp. 2d 472, 478 (S.D.N.Y. 2005) (citing In re Global Crossing, Ltd. Sec. Litig., 322 F. Supp. 2d 319, 339 (S.D.N.Y. 2004)). The plaintiffs in Worldcom alleged that Worldcom engaged in manipulation of the accounting entries. Specifically, the plaintiffs alleged that Worldcom was illegally shifting expenses into the capital accounts. The plaintiffs also alleged that there were a series of "high-level" accounting adjustments that bypassed the accounting system. In an interesting exchange, a WorldCom employee "went to . . . the Director of General Accounting, and told ... [the Director] that he needed to understand the one page of adjusting entries better. [The Director] said, 'if you show that ... piece of paper to our auditors, I'll throw you out of that ... window." Id. at 477-78.

41 See Ezra Charitable Trust v. Tyco Int'l., Ltd. 466 F.3d 1, 6 (1st Cir. 2006) (“[A] securities fraud claim has six elements: (1) a material misrepresentation or omission; (2) scienter; (3) connection with the purchase or sale of a security; (4) reliance; (5) economic loss; and (6) loss causation . . O Our focus here is on the adequacy of plaintiffs' allegations of scienter. Scienter is defined as 'a mental state embracing intent to deceive, manipulate, or defraud,' and a plaintiff must allege that 'defendants consciously intended to defraud, or that they acted with a high degree of recklessness."').

Id. (citation omitted). See also Paul M. Clikeman, Called to Account: Fourteen Financial Frauds that Shaped the American Accounting Profession (2009).

${ }^{42}$ It is reported that during the incident of the Tulipomania hysteria, "[p]eople of all grades converted their property into cash, and invested it in flowers. Houses and lands were offered for sale at ruinously low prices, or assigned in payment of bargains made at the tulipmart." MACKAY, supra note 10 , at 94 .

43 In 1979, the Hunt brothers and their associates allegedly attempted to corner the silver market by purchasing futures contracts while at the same time acquiring millions of ounces in silver. The apparent scarcity in silver would eventually result in a huge windfall to the Hunt brothers. Silver prices rose from $\$ 11$ per ounce in September 1979 to a peak of about $\$ 50$ an ounce in January 1980. 
affected individuals, are limited in scope when considered within the broader context of society. However, a new category of financial ruin lurks in our midst-accounting standards manipulation. Unlike its counterparts, this new category has the potential to reach further and may lead to widespread financial ruin. Accounting standards manipulation results from a combination of factors that includes a lack of meaningful regulatory guidance by the SEC in establishing accounting standards, the creation of malleable accounting standards by private standard setters, and unregulated management discretion when selecting the accounting standards to be used in preparing financial statements.

\section{ECONOMIC Trifecta or BERMUdA Triangle?}

The SEC's failure to create and regulate accounting standards actively benefits the business sector. Three policies combine to create an environment which grants corporate managers near unbridled discretion in reporting financial results: flexible accounting standards, management discretion, and judicial deference. Flexible accounting standards have developed as a result of the accounting profession's belief that elastic accounting standards will generate reliable financial information. ${ }^{44}$ Moreover, company managers have the discretion to choose among alternate GAAP standards under the premise that they are in the best position to select the applicable standard for the company. ${ }^{45}$ Finally, courts generally defer to economic decisions made by company managers. The culmination of these three doctrines creates an environment ripe for abuse of discretion, distorted financial results, and a pursuit of self interest - all at great shareholder and public expense. ${ }^{46}$

The price of silver eventually collapsed below $\$ 11$ an ounce within two months of its $\$ 50$ high. See Kurt Eichenwald, 2 Hunts Fined and Banned from Trades, N.Y. TimES, Dec. 21, 1989, available at http://www.nytimes.com/1989/12/21/business/2-hunts-fined-and-banned-from-trades.html (last visited Sept. 13, 2010).

44 See Financial Accounting Standards Board, Statement of Financial Accounting CONCEPTS NO. 2, at 21 (1980) ("E]ach decision maker judges what accounting information is useful.").

45 See Shalala v. Guernsey Mem'l Hosp., 514 U.S. 87, 101 (1995).

46 These three factors give rise to a moral hazard, defined in this article "as carelessness and indifference which may not suggest moral deficiency but still refer to personality traits which react with the security of . . protection." Bob Works, Excusing Nonoccurrence of Insurance Policy Conditions in Order to Avoid Disproportionate Forfeiture: Claim-Made Formats as a Test Case, 5 CONN. INS. L.J. 505 n.256 (1999). 
The philosophical approach and justification for American economic jurisprudence reaches back to sixteenth century Europe. However, Adam Smith's philosophy "against government interference in economic matters[,] massively influenced late eighteenth century and nineteenth century politicians. Smith provided politicians with an academic cloak of respectability with which to justify their policy aims and ideas, in particular, the desire for unbridled industrialization." 47 American capitalism, premised on Adam Smith's philosophy, similarly advocates for economic freedom and minimal government intrusion. ${ }^{48}$ It also favors a clear separation of the economy and the state. Smith's philosophical approach was evident throughout the formative years of the United States as farmers resisted government regulation. ${ }^{49}$ Later, when the industrialists arrived, they also resisted regulation. As the American economy transitioned from agricultural and industrial based economies to a more service-oriented economy, resistance to increased regulation continued. In fact, the business sector defends much of its resistance to economic regulation on the basis that the regulation would result in increased costs without a corresponding benefit. ${ }^{50}$

Nevertheless, America's affinity with the laissez-faire philosophy raises considerable questions concerning its effectiveness within our economic and regulatory framework. Oppressive regulation is not welcome, but neither is lax regulation. $^{51}$ While the traditional policy of economic non-intervention has served

\footnotetext{
${ }^{47}$ JOHN RiCHARD EDwARDS, A History OF FinANCIAL ACCOUNTING 188 (1989).

48 Roy C. SMITH, AdAM SMith AND the ORIGINS OF AMERICAN ENTERPRISE: HOW THE FOUNDING FATHERS TURNED TO A GREAT ECONOMIST'S WRITINGS AND CREATED THE AMERICAN ECONOMY 203 (2002) (“America’s long-term economic development followed essential Smithian policies. . . . In time, these [Smithian] principles ... were embedded in the essential American economic fabric.”).
}

49 See Harold U. FaulKner, The Decline of Laissez Faire, 1897-1917 21(1951) (“The battle for economic and political reform ... seemed lost and the nation committed to laissez faire and a continuation of older ideals and methods."). Lack of opposition was not just limited to farmers during this period: "Generally speaking, the masses brought no pressure on government to restrict or supervise the operation of private business until the conduct of such business became obviously disastrous or dangerous to the public welfare." Id. at 366.

${ }^{50}$ One commentator notes that "[a] common allegation is that the 'Plain English' initiative-- which requires issuer disclosure documents to be written in clear, simple language-- is another costly initiative imposed on companies." Alicia Davis Evans, A Requiem for the Retail Investor?, 95 VA. L. REV. 1105, 1112 (2009).

${ }^{51}$ Koenig, supra note 16, at 1037-38. 
U.S. interests well in the past, more recent events in the capital markets raise legitimate questions about accounting standards' development and their limitations when developed by private standard setters. ${ }^{52}$ Therefore, the SEC's approach of deferring to private standard setters in formulating GAAP should be questioned.

$$
\text { A. GAAP's Flexibility }
$$

GAAP is not an absolute measure of the current financial state of the company. Rather, it is a system of estimates that is used to determine the relative financial state of the company. The United States Supreme Court recognizes that:

GAAP is not the lucid or encyclopedic set of pre-existing rules that [some] might perceive it to be. Far from a single source accounting rulebook, GAAP "encompasses the conventions, rules, and procedures that define accepted accounting practice at a particular point in time." GAAP changes and, even at any one point, is often indeterminate. "[T]he determination that a particular accounting principle is generally accepted may be difficult because no single source exists for all principles." 53

GAAP is complex,${ }^{54}$ confusing, ${ }^{55}$ and at times, contradictory. ${ }^{56}$ Individuals and investors alike are astonished to learn that the only accurate number reported on most financial statements are the cash account and certain liabilities such as notes

52 See Gary Giroux, Earnings Magic and the Unbalance Sheet: The Search for FINANCIAL REALITY 31 (2006).

53 Shalala v. Guernsey Mem’l Hosp., 514 U.S. 87, 101 (1995) (citations omitted). But see FinANCIAL Accounting Standards Board, Statement of Financial Accounting Standards No. 168 (2009) (codifying GAAP in one source) [hereinafter FAS No. 168].

54 "Investor Warren Buffett, a billionaire and one of the most sophisticated investors in the world, has said, 'For more than forty years, I've studied the documents that public companies file. Too often, I've been unable to decipher just what is being said." Evans, supra note 50, at 1112.

55 See Egelhof v. Szulik, No. 04 CVS 11746, 2006 WL 663410, at *3 (N.C. Super. Ct. Mar. 13, 2006) (observing that "[e]vidently ... two different partners at PWC who advised [the company] on the [revenue recognition] issue interpreted 'ratably' differently under GAAP rules”).

56 "Unfortunately, GAAP is not found in a single source. Instead, in the United States, GAAP consists of a hodgepodge of accounting sources, which find their respective places in the hierarchical structure established by the American Institute of Certified Public Accountants ("AICPA")." Bolt v. Merrimack Pharm. Inc., 503 F.3d 913, 918 n.6 (9th Cir. 2007) (citation omitted). 
payable. $^{57}$ The remaining numbers, although perceived by most readers as absolute, are merely reported estimates using methods prescribed by GAAP. ${ }^{58}$ As noted by one court, "[t]he term '[GAAP]' . . encompass[es] a wide range of acceptable procedures, such that 'an ethical, reasonably diligent accountant may choose to apply any of a variety of acceptable accounting procedures when that accountant prepares a financial statement." $" 59$

Understanding GAAP, therefore, requires understanding the nature and function of an accounting principle. GAAP is defined as accounting principles that are "issued by the Financial Accounting Standards Board for use by accountants in preparing financial statements. The principles include not only broad guidelines of general application but also detailed practices and procedures." ${ }^{100}$ Furthermore, GAAP is "based on flexible accounting concepts, which, when applied, do not always (or perhaps ever) yield a single correct figure." ${ }^{.11}$

GAAP rules are flexible and permissive. ${ }^{62}$ The choice of accounting principles is determined by management after due attention to historical, economic, and tax considerations. For example, GAAP rules permit management a fair degree of discretion when determining accounts receivable, establishing inventory values, ${ }^{63}$

\footnotetext{
${ }^{57}$ Not all liabilities reflect a fixed and determinable value. Some liabilities such as pension, warranty or coupon redemptions are determined using estimates.

58 Examples of accounts which are estimates include, accounts receivables, inventories, pension liabilities, revenues and expenses.

59 Lovelace v. Software Spectrum Inc., 78 F.3d 1015, 1021 (5th Cir. 1996) (quoting Godchaux v. Conveying Techniques, Inc., 846 F.2d 306, 315 (5th Cir. 1988)).

${ }^{60}$ BLACK'S LAW DiCTIONARY 705 (8th ed. 2004).

${ }^{61}$ In re GlenFed, Inc. Sec. Litig., 42 F.3d 1541, 1549 (9th Cir. 1994) (en banc).

62 See In re IKON Office Solutions Inc. Sec. Litig., 194 F.R.D. 166, 171, 182 (2000) (explaining that while plaintiffs alleged that the "defendants engaged in a fraudulent scheme to falsify Ikon's financial results and issue aggressive financial projections for which defendants lacked a reasonable basis[,]" they conceded that GAAP "standards are somewhat flexible and that their application required judgment calls").

${ }^{63}$ Acceptable GAAP methods include, specific identification, average cost, first-in, first-out (FIFO), last-in, first-out (LIFO) and lower-of-cost-or-market (LCM). See DonAlD E. KIESO ET AL., INTERMEDIATE ACCOUNTING 394-98 (13th ed. 2007) (illustrating the comparative results of the Average Cost, FIFO and LIFO methods).
} 
reporting contingencies ${ }^{64}$ or determining asset impairments. ${ }^{65}$ Determining these amounts involves considerable management discretion, which ultimately affects the financial results reported.

In June 2009, the Financial Accounting Standards Board ("FASB") issued the Statement of Financial Accounting Standards ("FAS") No. 168 which codified all of GAAP in one source. ${ }^{66}$ Prior to the issuance of FAS No. 168, GAAP authorities were scattered throughout the accounting and academic literature. Finding an applicable rule, however, may continue to be a challenging process for both compliance and enforcement efforts because GAAP itself continues to be susceptible to multiple interpretations and applications. Furthermore, for periods before the enactment of FAS No. 168, finding an applicable GAAP rule was a difficult process for litigants. ${ }^{67}$ This difficulty most likely will continue into the future.

64 See Financial Accounting Standards Board, Statement of Financial Accounting STANDARD NO. 5 (1975).

65 See Financial accounting Standards BoArd, Statement of Financial Accounting STANDARDS No. 144 (2001). See also KIESO ET AL., supra note 63, at 534 ("The going concern concept assumes that the company can recover the investment in its assets. Under GAAP companies do not report the fair value of long-lived assets because a going concern does not plan to sell such assets. However, if the assumption of being able to recover the cost of the investment is not valid, then a company should report a reduction in value.").

66 Financial Accounting Standards Board, Statement of Financial Accounting STANDARDS NO. 168, at 2 (2009).

${ }^{67}$ Bolt v. Merrimack Pharm. Inc., 503 F.3d 913, 918 n.6 (9th Cir. 2007) (citations omitted) ("There are five categories in the GAAP hierarchy. Officially established accounting principles, referred to as Category (a) authority, are the highest level and include the Financial Accounting Standards Board ("FASB") Statements of Financial Accounting Standards and Interpretations, Accounting Principles Board ("APB") Opinions, and AICPA Accounting Research Bulletins. Moreover, Securities Exchange Commission ("SEC") rules and interpretative releases take an authoritative weight similar to Category (a) authority for companies registered with the SEC. Category (b) authority, the next highest level, consists of FASB Technical Bulletins and, if cleared by FASB, AICPA Industry Audit and Accounting Guides and AICPA Statements of Position. The third level of authority, Category (c), consists of AICPA Accounting Standards Executive Committee Practice Bulletins that have been cleared by FASB and consensus positions of the FASB Emerging Issue Task Force. Category (d), the fourth level of authority, consists of AICPA accounting interpretations and implementation guides published by the FASB staff, and practices that are widely recognized and prevalent either generally or in the industry. In the absence of established accounting principles, auditors may consider accounting literature in the fifth and final level of authority, which includes FASB Statements of Financial 


\section{B. Management Discretion in Selecting Accounting Principles}

It is a basic tenet of corporate law that "[a]ll corporate powers shall be exercised by or under the authority of the board of directors of the corporation." 68 Additionally, "[i]n the case of a public corporation, the board's oversight responsibilities include attention to . . [ [the] preparation of the corporation's financial statements." 69

Management has the responsibility of determining which accounting rules to adopt. The SEC states that "[ $\mathrm{t}]$ he fundamental and primary responsibility for the accuracy of information filed with the Commission and disseminated among the investors rests upon management. Management does not discharge its obligations in this respect by the employment of independent public accountants, however reputable."70 SEC Release No. 33-8040 further demonstrates this point by stating "the selection and application of the company's accounting policies must be appropriately reasoned." I1 It further states that "[m]anagement should be able to defend the quality and reasonableness of the most critical policies."72 Additionally, Opinion of the Accounting Principles Board ("APB") No. 22 provides that "accounting policies of a reporting entity are the specific accounting principles . . . judged by the management of the entity to be the most appropriate in the circumstances to present fairly [the] financial position, changes in financial position, and results of operations in accordance with generally accepted accounting principles."73 This approach by the APB reinforces the notion that management, in selecting among the accounting standards, has flexibility measuring, recording, and

Accounting Concepts; APB Statements; AICPA Issues Papers; International Accounting Standards of the International Accounting Standards Committee ("IASC"); Governmental Accounting Standards Board ("GASB") Statements, Interpretations, and Technical Bulletins; pronouncements of other professional associations or regulatory agencies; AICPA Technical Practice Aids; and accounting textbooks, handbooks, and articles.”).

${ }^{68}$ Model Business Corporation ACt \8.01(b) (2005).

${ }^{69}$ MOdel Business CORPORATION ACT $\int 8.01$ (c)(5) (2005).

70 Accounting Series Release No. 62, Securities Act Release No. 3234, 15 Fed. Reg. 9104, 9104 (June 27, 1947).

${ }^{71}$ SEC Release No. 33-8040, 66 Fed. Reg. 65013, 65013 (Dec. 17, 2001).

${ }^{72} I d$.

73 Accounting Principles Board of the American institute of Certified Public Accountants, Opinions of the Accounting Principles Board No. 22 ฯ 6 (1972). 
reporting a financial event. As noted by one commentator, "[A]ccounting permits alternative presentations for a particular transaction or account."

Although accountants and business managers favor discretion and flexibility in selecting accounting principles, such discretion and flexibility also creates unintended opportunities to fabricate the earnings of the company ${ }^{75}$ and distort the fundamental economic activity of the company. ${ }^{76}$ Concerned with the excess that such flexibility provides, Arthur Levitt, former Chairman of the SEC, remarked that:

[F]lexibility in accounting allows it to keep pace with business innovations. Abuses such as earnings management occur when people exploit this pliancy. Trickery is employed to obscure actual financial volatility. This, in turn, masks the true consequences of management's decisions. These practices aren't limited to smaller companies struggling to gain investor interest. It's also happening in companies whose products we know and admire. ${ }^{77}$

The SEC has observed that "[t]oo often, accounting and disclosure rules are disregarded in order that revenues and earnings . . . be inflated improperly to meet earnings projections of analysts or others in the financial community or to achieve some other objective." 78

${ }^{74}$ Jeffrey N. Gordon, The Rise of Independent Directors in the United States, 1950-2005: Of Shareholder Value, 59 STAN. L. REV. 1465, 1558 (2007).

75 Earnings management can be traced as far back as 1848 when corporate managers "employ[ed] valuation procedures designed principally to produce a pattern of reported profit sufficient to cover the planned level of dividend." See EDWARDS, supra note 47, at 117.

76 Accounting Principles BoArd of the American Institute of Certified Public Accountants, Opinions of the Accounting Principles Board No. 20, at 15 (1971) (“ [] n the preparation of financial statements there is a presumption that an accounting principle once adopted should not be changed in accounting for events and transactions of a similar type.").

77 Arthur Levitt, Chairman, Securities and Exchange Commission, Remarks at the NYU Center for Law and Business 3 (Sept. 28, 1998) (transcript available at http://www.sec.gov/news/speech/ speecharchive/1998/spch220.txt). Arthur Levitt further remarked, "Five of the more popular [accounting illusions] I want to discuss today are 'big bath' restructuring charges, creative acquisition accounting, 'cookie jar reserves,' 'immaterial' misapplications of accounting principles, and the premature recognition of revenue." Id. at 4.

${ }^{78}$ Informix Corp., Securities Act Release 7788, Exchange Act Release No. 42326, 2000 SEC LEXIS 34, at $* 41$ (Jan. 11, 2000). 
In re Netflix Inc. Securities Litigation ("In re Netflix") 79 is a stunning example demonstrating the wide discretion that management enjoys when selecting accounting principles. In re Netflix involved a novel company-created measurement in place of a recognized industry standard or a method recommended by the auditors. The defendant, Netflix Inc. ("Netflix"), sold "monthly subscriptions allowing people to order DVD's on the Internet and to receive them by mail." 80 Since April 16, 2002, Netflix publicly reported a steadily decreasing churn rate ${ }^{81}$ from a high of $8 \%$, to a "record low" of $4.7 \%$ by April 15, 2004. The "churn rate" 82 reflects the number of subscribers who "cancelled their [video product] subscriptions each month." 83 Because Netflix relied heavily on monthly subscriptions, subscriber cancellations were critical to its business model. Netflix management made a series of announcements which negatively affected the company's stock price. For example, management announced plans for a price increase, reported "delay[ed] plans to expand into the United Kingdom, [and] downgraded its earnings forecast from $\$ 80$ million to zero." ${ }^{\prime 44}$ As a result, Netflix's stock price "cratered" from a high of $\$ 32$ in mid-July 2004 to a low of $\$ 10.30$ by mid-October 2004. ${ }^{85}$ The plaintiffs claimed that Netflix made a series of "false and misleading statements, and failed to disclose materials facts." ${ }^{\prime 6}$ The plaintiffs alleged that Netflix misled them, because Netflix miscalculated the churn rate. Specifically, the plaintiffs claimed that Netflix was "using a misleading calculation of . . . the average subscriber cancellation rate." churn rate" method was misleading and that instead, Netflix should have calculated the churn rate by using the preferred industry standard, or in the alternative, the

${ }^{79}$ In re Netflix, Inc. Sec. Litig., No. C 04-2978 WHA, C 04-3021, C 04-3204, C 04-3233, C 04-3329, C 04-3370, C 04-3801, 2005 WL 3096209 (N.D. Cal. Nov. 18, 2005).

${ }^{80} I d$. at $* 1$.

${ }^{81}$ Churn rates measure the percentage of customer cancellations. A high churn rate suggests a high customer cancellation rate for the period measured. In contrast, a low churn rate suggests a low customer cancellation rate.
82 Netflix, 2005 WL 3096209, at*2.
${ }^{83} \mathrm{Id}$. (internal quotation marks omitted).
${ }^{84} I d$. at $* 4$.
${ }^{85} \mathrm{Id}$. at $* 4$.
${ }^{86} I d$. at $* 1$.
${ }^{87} \mathrm{Id}$. 
standard proposed by its auditors. ${ }^{88}$ Plaintiffs conceded, however, that there was no applicable GAAP for churn rates. ${ }^{89}$

The court dismissed the plaintiffs" complaint reasoning that "[t]his is not a case in which defendants used one calculation method when another is mandated by industry practice, generally accepted accounting principles[,] or federal securities regulations ... Plaintiffs cite no statute or SEC regulation barring Netflix from reporting its type of churn rates." The court further reasoned that "the critical key to understanding defendants' methodology was adequately and repeatedly disclosed." 91 The court concluded that "[t]he use of a unique measure in and of itself does not render their reports false and misleading ... There are no plain-English definitions of these financial measures. They are, like all statistics, artificial constructs." ${ }^{92}$

The court's resolution in In re Netflix is interesting because it suggests that, in the absence of a stated GAAP principle, companies have considerable discretion in crafting their own financial standard, so long as the methodology is disclosed. This interpretation is favorable to companies when novel accounting issues present themselves and private standard setters are slow to follow. Under these circumstances manipulation becomes irresistible.

Admittedly, management is in the best position to know the salient features affecting a company's operations. Nonetheless, there is often the individual temptation and external pressure to select accounting principles which will place the company in a favorable light. This is especially evident where management has stock options that are based on the performance of the company. ${ }^{93}$ As noted by Arthur Levitt:

$88 \mathrm{Id}$. at *6. The two methods are: " 1 . The number of cancellations in the month divided by the number of subscribers at the month's start. This is the method described by KPMG. 2. The number of cancellations in the month divided by the average number of subscribers at any one point during the month." Id. This method is referred to as "true churn." Id.

${ }^{89} \mathrm{Id}$.

${ }^{90} I d$. at $* 9$.

${ }^{91} I d$.

${ }^{92} I d$. at $* 10$ (emphasis in original).

93 See In re IMAX Sec. Litig., 587 F. Supp 471, 480 (S.D.N.Y. 2008) (citations omitted) ("The mere fact that an individual defendant's executive compensation is dependent on stock value or entails some 
[T]ncreasingly, I have become concerned that the motivation to meet Wall Street earnings expectations may be overriding common sense business practices. Too many corporate managers, auditors, and analysts are participants in a game of nods and winks. In the zeal to satisfy consensus earnings estimates and project a smooth earnings path, wishful thinking may be winning the day over faithful representation. ${ }^{94}$

\section{Judicial Deference}

Courts routinely defer to the judgment of corporate management with respect to matters of corporate policy and business objectives. ${ }^{95}$ Reasons of efficiency, economy, and competence account for this approach. The philosophy of judicial deference is articulated in Kamin v. American Exp. Co. ${ }^{96}$ where Judge Greenfield stated that:

other performance-based component cannot, by itself, support an inference of scienter ... Nor can plaintiffs establish [wrongful] motive by simply pointing to the lucrative change-of-control provisions in . . . employment agreements."). But see Robert W. Holthausen, Annual Bonus Schemes and the Manipulation of Earnings, 19 J. ACCT. \& Econ. 29 (1995) (maintaining that corporate managers manipulate year end accruals to maximize compensation plans based on the earnings of the company).

${ }^{94}$ Levitt, supra note 77, at 2 (emphasis added); see also, FINANCIAL ACCOUNTING STANDARDS BOARD, StATEMENT OF FinANCiAL ACCOUNTING CONCEPTS No. 2, at 27 (1980) ("Representational faithfulness is correspondence or agreement between a measure or description and the phenomenon it purports to represent. In accounting, the phenomena to be represented are economic resources and obligations and the transactions and events that change those resources and obligations.").

95 Boston \& Albany Railroad Co. v. New York Central Railroad Co. is an early case illustrating judicial notice of a method of accounting (depreciation):

The method of determining depreciation by taking as a basic cost book value, or reproduction of property which will deteriorate with use, and deducting therefrom a percentage for the time it has been in use based upon the probable length of its life, has been in principle either approved by the court or held to be not wrong as matter of law.

Boston \& Albany R.R. Co. v. New York Cent. R.R. Co., 153 N.E. 19, 23 (Mass. 1926) (citing Mayor and Alderman of Knoxville v. Knoxville Water Co., 212 U.S. 1 (1909); Lapham v. Tax Comm'r, 138 N.E. 708 (Mass. 1923); City of Boston v. Treasurer \& Receiver Gen., 130 N.E. 390, 393 (Mass. 1921); Stein v. Strathmore Worsted Mills, 108 N.E. 1029 (Mass. 1915)).

96 Kamin v. Am. Express Co., 383 N.Y.S.2d 807 (N.Y. Sup. Ct. 1976), aff'd, 387 N.Y.S.2d 993 (N.Y. App. Div. 1976). 
Questions of policy of management, expediency of contracts or action, adequacy of consideration, lawful appropriation of corporate funds to advance corporate interests, are left solely to [the director's] honest and unselfish decision, for their powers therein are without limitation and free from restraint, and the exercise of them for the common and general interests of the corporation may not be questioned, although the results show that what they did was unwise or inexpedient. ${ }^{97}$

The approach by the courts of deferring to the business judgment of company management is evident in matters concerning dividend policy, ${ }^{98}$ pursuing a new line of business, ${ }^{99}$ or taking neighborhood interests into consideration. ${ }^{100}$

Courts are not predisposed to second guess the legitimate business decision of a corporate manager. ${ }^{101}$ This line of reasoning is commonly referred to as the "business judgment rule."102 The court in Aronson v. Lewis ${ }^{103}$ formulated the business judgment rule as:

a presumption that[,] in making a business decision[,] the directors of a corporation acted on an informed basis, in good faith[,] and in the honest belief that the action taken was in the best interests of the company. Absent an abuse of discretion, that judgment will be

\footnotetext{
${ }^{97}$ Id. at 811 (quoting Pollitz v. Wabash R.R. Co., 100 N.E. 721, 724 (N.Y. 1912)).

${ }^{98} \mathrm{Id}$. at 810 ("[T] he question of whether or not a dividend is to be declared or a distribution of some kind should be made is exclusively a matter of business judgment for the Board of Directors.").

99 See generally Stephen M. Bainbridge, The Business Judgment Rule as Abstention Doctrine, 57 VAND. L. REV. 83 (2004) (advocating for the Business Judgment Rule as an abstention doctrine given that most corporate decisions "do not pose much of a confict between the interest of directors and shareholders").

100 Shlensky v. Wrigley, 237 N.E.2d 776, 781 (Ill. App. Ct. 1968).

101 See FDIC v. Stahl, 89 F.3d 1510, 1517 (11th Cir. 1996). "The [Business Judgment Rule] is a policy of judicial restraint born of the recognition that directors are, in most cases, more qualified to make business decisions than are judges." Id. (quoting Int'l Ins. Co. v. Johns, 874 F.2d 1446, 1458 n.20 (11th Cir. 1989)).

102 Id. at $1514,1517$.

103 Aronson v. Lewis, 473 A.2d 805 (Del. 1984).
} 
respected by the courts. The burden is on the party challenging the decision to establish facts rebutting the presumption. ${ }^{104}$

In similar fashion, courts refrain from interfering with the selection of an accounting policy by management. This is especially true since GAAP offers management several alternatives when selecting accounting principles. ${ }^{105}$ It stands to reason that if courts are reluctant to second guess management on a prospective business decision, they are less likely to challenge management on the selection of accounting principles to be used for financial reporting.

The only meaningful limitation on management, when these three doctrines ${ }^{106}$ converge, is to restrict management from engaging in fraud or making a material misrepresentation. ${ }^{107}$ The flexibility in GAAP, the discretion that management enjoys in selecting among alternative GAAP rules, and the deference courts give business decisions, all have combined to generate substantial benefits for business in particular and for society in general. However, the convergence of these three policies has also exacted costly financial consequences on American society as the government is forced to assist failed companies who abused GAAP in the name of increasing shareholder value. ${ }^{108}$

\section{THE REGULATORY FRAMEWORK OF ACCOUNTING RULES}

\section{A. British Influence}

Accounting standards in the U.S. were first introduced by British accountants during the end of the nineteenth century, when the U.S. economy was dependent on the agricultural and manufacturing industries. ${ }^{109}$ The relatively few accounting standards evolved from a commercial framework where assets were tangible and easily verifiable. ${ }^{110}$ British accountants also imported a "tradition of treating

\footnotetext{
${ }^{104} I d$. at 812 (citations omitted).

${ }^{105}$ Lovelace v. Software Spectrum Inc., 78 F.3d 1015, 1021 (5th Cir. 1996).

106 The three doctrines are GAAP flexibility, management discretion, and judicial deference.

107 Aronson, 473 A.2d at 812.

${ }^{108}$ Levitt, supra note 77, at 3.

${ }^{109}$ EDWARDS, supra note 47, at 120-22.

${ }^{110} \mathrm{Id}$. at 123 .
} 
accounting as an extension of the law." 111 As a result, the accounting profession adopted the position that "financial reporting should be governed by principles and professional judgment, not blind conformance with arbitrary rules." 112

During the nineteenth century, accounting standards or, more appropriately, accounting practices, were heavily concentrated on the form and content of the financial presentation. ${ }^{113}$ Unlike present-day practices where judgment is pervasive, accounting practice during the late nineteenth century was predominantly a mechanical process involving little or no judgment. ${ }^{114}$ Accounting standards were rigid, highly mechanized, and focused almost exclusively on process. ${ }^{115}$ The posting and carrying of financial amounts was done in a prescribed manner following a prescribed order. ${ }^{116}$ The accounting principles that developed during this era focused primarily on the mechanics of accounting, as distinguished from the methods of accounting. ${ }^{117}$ By the late nineteenth century, Britain's accounting industry was wellformed with well-developed practices and procedures that eventually migrated into the U.S. business environment as domestic businessmen sought qualified accountants to satisfy the ever-increasing demand for financial information. ${ }^{118}$

Early accounting practices heavily emphasized the reporting of the balance sheet accounts to reflect the state of affairs and the assets available to a business. ${ }^{119}$ Eventually, the emphasis on balance sheet reporting was replaced with an emphasis on income statement reporting. ${ }^{120}$ This shift resulted because the management and ownership model transitioned from a proprietary model with sole or limited

111 Thomas A. King, More than a Numbers Game: A Brief history of Accounting 74 (2006).

$112 I d$.

${ }^{113}$ EDWARDS, supra note 47, at 125.

${ }^{114} I d$. at 110.

${ }^{115} I d$.

116 "The celebrated economist John B. Canning, writing in 1929, was totally disparaging of early writers on accountancy: 'they made little showing of any systematic thought, though they were sticklers for unswerving adherence to the technical procedure shown." Id. at 71 .

117 Id. at $124-25$.

118 Id. at 109.

${ }^{119} \mathrm{Id}$. at 128 .

${ }^{120} I d$. at 172. 
ownership and a focus on ownership of assets, to a corporate model with dispersed ownership and an increased interest in a dividend distribution policy. ${ }^{121}$

\section{B. Interstate Commerce Commission}

The Interstate Commerce Act of 1887 ("ICC") was the United States' first attempt to establish accounting standards. ${ }^{122}$ Congress enacted the ICC and created the Interstate Commerce Commission ("Commission") to address concerns raised by farmers in Western states about the practices of the railroad companies. ${ }^{123}$ These farmers had complained about the railroad companies' rate discrimination and influence peddling. To remedy the abuses, Congress authorized the Commission to "require annual reports ... and prescribe the manner in which such reports shall be made" by the railroad companies. ${ }^{124}$ Additionally, the Commission had statutory authority to "prescribe ... [,] as near as may be, a uniform system of accounts, and the manner in which such accounts shall be kept." ${ }^{\prime 25}$ Accounting principles, to the

${ }^{121} I d$. at 111.

122 Interstate Commerce Act of 1887, ch. 104, 24 Stat. 379 (1887).

${ }^{123} I d$. at sec. 20.

${ }^{124} I d$.

${ }^{125} \mathrm{Id}$. Section 20 of the Interstate Commerce Act of 1887 requires companies to furnish the Commission a detailed annual report. Id. No other federal legislation before had required such detailed information.

Section 20 provides:

$[\mathrm{T}]$ he Commission is hereby authorized to require annual reports from all common carriers subject to the provisions of this act, to fix the time and prescribe the manner in which such reports shall be made, and to require from such carriers specific answers to all questions upon which the Commission may need information. Such annual reports shall show in detail the amount of capital- stock issued, the amounts paid therefor [sic], and the manner of payment for the same; the dividends paid, the surplus fund, if any, and the number of stockholders; the funded and floating debts and the interest paid thereon; the cost and value of the carrier's property, franchises, and equipment; the number of employees and the salaries paid each class; the amounts expended for improvements each year, how expended, and the character of such improvements; the earnings and receipts from each branch of business and from all sources; the operating and other expenses; the balances of profit and loss; and a complete exhibit of the financial operations of the carrier each year, including an annual balance-sheet. Such reports shall also contain such information in relation to rates or regulations concerning fares or freights, or agreements, arrangements, or contracts with other common carriers, as the 
extent they existed during this period, "had largely been defined by academic writings and general industry practices." 126 The accounting profession itself was in its infancy and still developing as a professional organization. ${ }^{127}$

However, accounting standards in the U.S. began to take form in 1917 when attempts to standardize the auditor's report commenced. ${ }^{128}$ A report issued by the Federal Reserve Board in 1917 attempted to bring about uniformity in the preparation of financial statements used by banks and to deal with manufacturing and merchandising concerns. ${ }^{129}$ The report contained statements illustrating the preference for conservative accounting principles whenever financial statements were prepared. ${ }^{130}$ This report can be regarded as an initial attempt to create accounting principles. ${ }^{131}$

\begin{abstract}
Commission may require; and the said Commission may, within its discretion, for the purpose of enabling it the better to carry out the purposes of this act, prescribe (if in the opinion of the Commission it is practicable to prescribe such uniformity and methods of keeping accounts), a period of time within which all common carriers subject to the provisions of this act shall have, as near as may be, a uniform system of accounts, and the manner in which such accounts shall be kept.
\end{abstract}

Id. at sec. 20.

126 BARRy J. EPSTEIN ET AL., WILEY GAAP 2008 INTERPRETATION AND APPLICATION OF Generally ACCEPTED ACCOUNTING PRINCIPLES 2 (2007).

127 However, it was not until the Hepburn Act in 1906 that violations of accounting rules enacted under federal law could be enforced by fines or imprisonment. See Hepburn Act, ch. 3591, sec. 2, 34 Stat. 584 (1906).

128 See Federal Reserve Board, 3 Federal Reserve Bulletin No. 4, at 270 (1917).

${ }^{129} \mathrm{Id}$. at 270.

130 See $i d$. at 274 . "[W] here the market values of securities are less than the book values, save where the variation is so small as to be trifling, a reserve for loss in value on the balance sheet date must be set up." Id. at 274. "The auditor should satisfy himself that inventories are stated at cost or market prices, whichever are the lower at the date of the balance sheet. No inventory must be passed which has been marked up to market prices and a profit assumed that is not and may never be realized." Id. at 275. "The total of the balances at the beginning of the period must agree with the cost of property figures given in the balance sheet at that date." Id. at 276.

131 See id. at 270-84. 


\section{Federal Securities Acts}

The next attempt by the federal government to establish accounting standards followed the stock market crash of 1929. Congress passed the Securities Act $^{132}$ in 1933, which was aimed at eliminating abusive practices present in the capital markets before the crash, and authorized the Federal Trade Commission to administer it. ${ }^{133}$

Section 19(a) of the Securities Act provides that "[t]he Commission shall have authority ... to prescribe the form ... in which required information shall be set forth, the items ... to be shown in the balance sheet and earning statement, and the methods to be followed in the preparation of [the] accounts." ${ }^{134}$ The Securities Act requires that all companies registering securities for public distribution contain a balance sheet and an income statement that has been certified by an independent public or certified accountant. ${ }^{135}$ Additionally, Schedule A requires that an issuer ${ }^{136}$

132 See Securities Act of 1933, 15 U.S.C. SS 77a-77aa (2006).

133 Section 4 of the Exchange Act created the SEC. See 15 U.S.C. S 78d (2006). Authority for the administration and enforcement of the securities laws was transferred from the FTC to the SEC upon the enactment of the Exchange Act. Id.

13415 U.S.C. $\int 77$ s (2006) (emphasis added).

135 See 15 U.S.C. $\int 77$ aa (2006). There is no explanation offered in the committee reports distinguishing between an "independent" or a "certified" accountant. Id. The question of "who is an independent accountant" within the meaning of the Securities Act was answered by George C. Mathews in an address to the Illinois Society of Certified Public Accountants. George C. Mathews, Comissioner, Securities \& Exchange Commission Address, before the Illinois Society of Certified Public Accountants 32 (Jan. 18, 1935), available at http://www.sec.gov/news/speech/1935/ 011835mathews.pdf. Mathews remarked:

Perhaps the best way to answer the question is to quote from a letter which was sent by the Chief of the Securities Division of the Federal Trade Commission, at the time that that Commission administered the Securities Act, ... "With respect to the question of stock ownership [in the audited company], I do not believe that this can be answered categorically either with regard to the amount of stock which may be held or with regard to the persons by whom it may be held. A nominal stock holding which obviously would not influence the judgment of an accountant, would not, I believe, affect the accountant's independence. In any case, I believe that the stock holdings of all persons, either partners or employees, who are concerned with work for a particular client of an accounting firm, should be taken into consideration and I do not believe that a firm can be deemed independent if such stock holdings in any case, either directly or indirectly, are more than nominal in amount." 
of securities supply a prospective investor with a balance sheet ${ }^{137}$ and an income statement ${ }^{138}$ that has been "certified by an independent public or certified accountant." 139

President Franklin D. Roosevelt said in his message accompanying the Securities Act that "[ $t$ ]here is . . an obligation upon us to insist that every issue of new securities to be sold in interstate commerce shall be accompanied by full publicity and information, and that no essentially important element attending the issue shall be concealed from the buying public." ${ }^{140}$ President Roosevelt's message echoes the sentiment that Louis Brandies described 20 years earlier: "Sunlight is said to be the best of disinfectants; electric light[,] the most efficient policeman." "141 The national goal during this challenging period was to reverse the financial demise of the American economy. ${ }^{142}$ Congress envisioned attaining this goal through a system of reporting and disclosure. ${ }^{143}$ When passing the Securities Act, Congress remarked

Id.

13615 U.S.C. $\int 78 c(a)(8)$ (2006) (defining the term "issuer" in relevant part to mean "any person who issues or proposes to issue any security").

13715 U.S.C. $\int 77 \mathrm{aa}$ (2006) (requiring "a balance sheet as of a date not more than ninety days prior to the date of the filing of the registration statement showing all of the assets of the issuer ... [[a]nd] all of the liabilities of the issuer").

${ }^{138} I d$. (requiring "a profit and loss statement of the issuer showing earnings and income, the nature and source thereof, and the expenses and fixed charges in such detail and such form as the Commission shall prescribe).

139 Id. (requiring "a profit and loss statement of the issuer showing earnings and income... Such statement shall be certified by an independent public or certified accountant").

140 H.R. ReP. NO. 73-85, at 1-2 (1933) reprinted in 1 Federal SECuRities Laws: Legislative HISTORY 1933-1982, at 139-140 (1983).

141 Louis D. Brandeis, Other People's Money and How the Bankers Use It 92 (2d ed. 1932).

142 See H.R. ReP. No. 73-85, at 2 (1933), reprinted in 1 Federal SeCurities Laws: Legislative HISTORY 1933-1982, at 140 (1983).

143 Id. at 139 (explaining that "[t]he background of the President's message is only too familiar to everyone. During the post-war decade [of the 1920's] some 50 billion[] [dollars] of new securities were floated in the United States. Fully half or $\$ 25,000,000,000$ worth of securities floated during this period have been proved to be worthless. These cold figures spell tragedy in the lives of thousands of individuals who invested their life savings, accumulated after years of effort, in these worthless securities.") 
that "[o]ne would have to turn the pages of history back to the days of the South Sea Bubble to find an equivalent fantasy of security selling." 144

The following year, Congress passed the Exchange Act, which created the SEC for the purpose of monitoring and regulating the financial markets. ${ }^{145}$ The SEC's stated objective was to instill confidence in the capital markets. ${ }^{146}$ In contrast to the Securities Act, which addresses the primary market, Congress designed the Exchange Act to deal with the secondary markets. ${ }^{147}$

With one key distinction, the Exchange Act contained language substantially similar to the Securities Act's language concerning accounting standards regulation. ${ }^{148}$ The Exchange Act provides that "[t]he Commission may prescribe, in regard to reports made pursuant to this title, the form ... in which the required information shall be set forth, the items . . . to be shown in the balance sheet and the earnings statement, and the methods to be followed in the preparation of reports." ${ }^{\text {149 }}$ The key difference in language between the two pieces of legislation is that the Securities Act mandates the creation of accounting standards through the use of the word "shall", whereas the Exchange Act is more permissive with respect to standard setting with its use of the word "may."150 This subtle difference in language may account in part for the SEC's deferential posture with respect to setting accounting

${ }^{144} \mathrm{Id}$. at 140.

145 Securities Exchange Act of 1934, 15 U.S.C. SS 78a-78pp (2006).

14615 U.S.C. $\int 78 \mathrm{~d}$ (2006). The SEC is charged with the responsibility of protecting investors. Id. To that end, in addition to the Securities Act and the Exchange Act, Congress has passed several significant pieces of legislation, which include the Public Utility Holding Company Act of 1935, the Trust Indenture Act of 1939, the Investment Company Act of 1940, the Investment Advisers Act of 1940, the Securities Investor Protection Act of 1970, the Sarbanes-Oxley Act of 2002, and most recently, the Credit Rating Agency Reform Act of 2006. All of these acts have the common objective of protecting shareholders, instilling confidence in the capital markets and promoting transparency.

147 See id. at SS 78a-78pp. Black's Law Dictionary defines "primary market" as "[t]he market for goods or services that are newly available for buying and selling; esp. the securities market in which new securities are issued by corporations to raise capital" and "secondary market" as the "market for goods or services that have previously been available for buying and selling; esp., the securities market in which previously issued securities are traded among investors.” BLACK'S LAW DICTIONARY 989-90 (8th ed. 2004).

14815 U.S.C. $\iint 57 \mathrm{~s}(\mathrm{a}), 78 \mathrm{~m}(\mathrm{~b})(1)$ (2006).

${ }^{149} I d$. at $\ 78 \mathrm{~m}(\mathrm{~b})(1)$ (emphasis added).

${ }^{150} I d$. at $\iint 77 \mathrm{~s}(\mathrm{a}), 78 \mathrm{~m}(\mathrm{~b})(1)$. 
standards. However, by failing to enact accounting principles, the SEC left open a regulatory void that was quickly filled by the accounting profession.

\section{Administrative Guidance}

In the years following the enactment of the securities laws, the SEC made two significant policy announcements with respect to accounting standards. ${ }^{151}$ First, the SEC issued Accounting Series Release No. 4 (“ASR 4") in 1938, which provides:

In cases where financial statements filed with this commission[,] pursuant to its rules and regulations under the Securities Act . . . or the .. . Exchange Act . . . [,] are prepared in accordance with accounting principles for which there is no substantial authoritative support, such financial statements will be presumed to be misleading or inaccurate despite disclosures contained in the certificate of the accountant or in footnotes to the statements[,] provided the matters involved are material. In cases where there is a difference of opinion between the Commission and the registrant as to the proper principles of accounting to be followed, disclosure will be accepted in lieu of correction of the financial statements themselves only if the points involved are such that there is substantial authoritative support for the practices followed by the registrant and the position of the Commission has not previously been expressed in rules, regulations or other official releases of the Commission, including the published opinions of its chief accountant. ${ }^{152}$

The purpose of issuing ASR 4 was to provide public guidance concerning how financial statements should be prepared when submitted to the SEC. ${ }^{153}$ However, ASR 4 fails in several respects. First, nowhere does it indicate how or where one finds "substantial authoritative support." "54 Second, nowhere does it define what is meant by the terms "substantial" or "authoritative," which leaves the application of

151 See Securities \& Exchange Commission, Accounting Series Release No. 4 (1938) [hereinafter ASR 4]; see also 17 C.F.R. \210.1-01 (2009).

152 ASR 4, supra note 151. The second sentence of ASR 4 is significant because it signals a conciliatory tone by the SEC, thereby reinforcing the perception that "difference[s] of opinion between the Commission and the registrant" will be tolerated. Id.

153 See id.

${ }^{154} I d$. 
this point unclear and subject to multiple interpretations. ${ }^{155}$ Finally, nowhere does ASR 4 indicate what criterion shall be used when crafting accounting principles. ${ }^{156}$

The SEC's enactment of Regulation S-X in 1940 was the second significant action taken with respect to accounting standards. ${ }^{157}$ Regulation S-X "sets forth the form and content of and requirements for financial statements required to be filed [with the SEC.]"158 Regulations S-X also sets forth requirements concerning auditor independence and general instructions for financial statements. ${ }^{159}$ Although Regulation S-X has repeated references to GAAP, it does not define GAAP. ${ }^{160}$ Regulation S-X "does not by itself define or impose any limitations or prerequisites concerning the accounting principles and practices used in preparing [financial] statements." ${ }^{161}$ Instead, Regulation S-X is singularly focused on the form of financial statement presentation. ${ }^{162}$ The more compelling issues, namely the methods, processes, and standards of measurement, are nowhere mentioned. ${ }^{163}$

Few accounting standards and no official GAAP standards existed when the Exchange Act was passed. ${ }^{164}$ Indeed, Carman G. Blough, Chief Accountant of the Securities and Exchange Commission, remarked:

Many accountants would probably question the soundness of certain principles that they follow from day to day if they stopped to

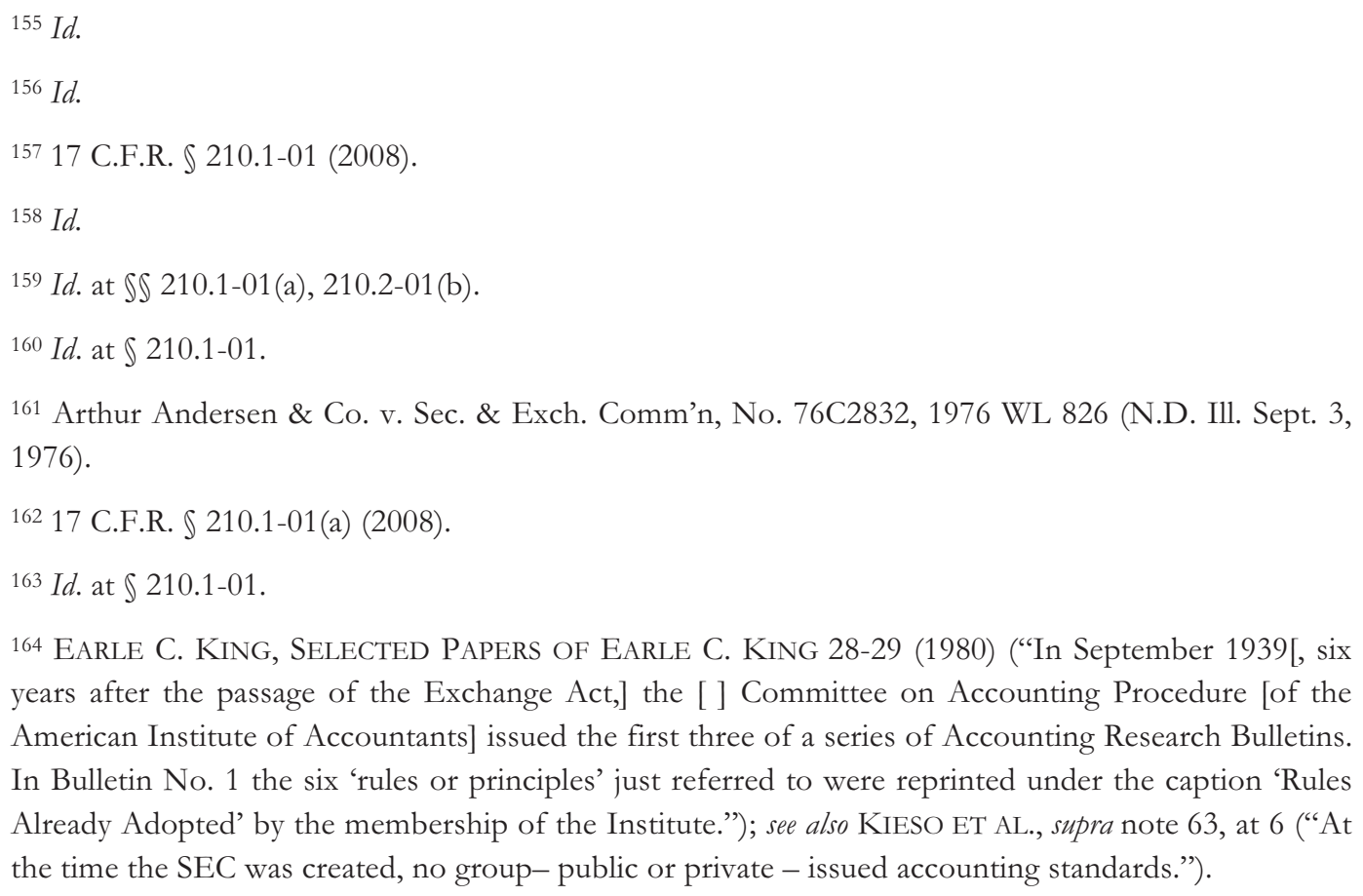
years after the passage of the Exchange Act,] the [] Committee on Accounting Procedure [of the American Institute of Accountants] issued the first three of a series of Accounting Research Bulletins. In Bulletin No. 1 the six 'rules or principles' just referred to were reprinted under the caption 'Rules Already Adopted' by the membership of the Institute."); see also KIESO ET AL., supra note 63, at 6 (“At the time the SEC was created, no group- public or private - issued accounting standards.”). 
consider them, but, in many cases, they follow the precedent of other accountants or the opinions of recognized authorities in whom they have confidence without reasoning the problem through to their own satisfaction. ${ }^{165}$

Established GAAP standards finally began appearing soon after the advent of national accounting organizations. ${ }^{166}$ Over time, GAAP evolved in importance as the American economy matured from local economic communities, to integrated regional, national, and now international economic communities. Shareholders, managers, accountants, courts, legislators, and the public rely on GAAP as the financial yardstick by which to measure financial performance. Noticeably absent, however, was a standard with which to create and characterize new GAAP standards. ${ }^{167}$

165 Carman G. Blough, Chief Accountant, Securities \& Exchange Commission, Address before the New York State Society of Certified Public Accountants: Some Accounting Problems of the Securities and Exchange Commission (Jan. 11, 1937), available at http://c0403731. cdn.cloudfiles.rackspacecloud.com/collection/papers/1930/1937_0111_BloughNewYorkCPAT.pdf. Blough added:

You all know how precedents of this kind may become established. An accountant has a peculiar situation that he thinks may best be treated by some digression from what he himself considers to be the best practice under normal circumstances. Again a very positive and valued client has taken a position contrary to the accountant's best judgment but, in the particular case, the accountant, because he thinks the principle at stake is not sufficiently important to cause him to withdraw, accedes to the wishes of his client. After a few cases of this kind by reputable firms, some accountant, hurried in a job, accepts such precedent without giving careful thought to the problem. Subsequently, some textbook writer relates the practice as an example of a procedure followed in some instances and this is, in turn, cited by others in support of the practice. Thus a large body of precedent is established for a procedure that was first reluctantly undertaken as an exception.

Id.

${ }^{166}$ King, supra note 164, at 28-29.

167 The accounting profession eventually published a "conceptual framework" in May 1980. See FinANCIAL ACCOUNTING STANDARDS BOARD, STATEMENT OF FINANCIAL ACCOUNTING CONCEPTS NO. 2, at 8 (1980) (describing the conceptual framework as "a coherent system of interrelated objectives and fundamentals that is expected to lead to consistent standards"). One writer describes the conceptual framework as "a constitution." KIESO ET AL., supra note 63, at 32. 


\section{E. Diverging from Congressional Policy?}

Accountants recognized six standards during the 1930s. ${ }^{168}$ Therefore, a fair question to consider is whether Congress envisioned the surge of accounting standards from those it may have initially contemplated when it passed both the Securities Act and the Exchange Act. The answer to this question is not entirely clear. However, what is clear is that when Congress enacted the Securities Act and the Exchange Act, it placed its confidence in the belief that audited financial statements would produce accurate financial reporting. ${ }^{169}$ It is also clear that when Congress was busy implementing the newly enacted securities laws, the accounting profession was growing increasingly concerned with its legal exposure from certifying financial statements. ${ }^{170}$ The Supreme Court of New York stated that "[a]ccountants ... are commonly employed for the very purpose of detecting defalcations which the employer's negligence has made possible. Accordingly, we see no reason to hold that the accountant is not liable to his employer in such cases." ${ }^{171}$

\footnotetext{
168 See Earle C. King, Chief Accountant, Securities \& Exchange Commission, Address before the Wisconsin Society of Certified Public Accountants: Generally Accepted Accounting Principles (Oct. 15, 1948), available at http://www.sec.gov/news/speech/1948/101548king.pdf (reporting that "[i]n September 1939, the Committee on Accounting Procedure of the American Institute of Accountants [adopted] . . . the six 'rules or principles' . . . under the caption 'Rules already adopted' by the membership of the Insititute"); see also Maurice Moonitz, Some Difficulties in the Pursuit of Accounting Principles, http://sunzi.lib.hku.hk/hkjo/view/12/1200037.pdf (last visited Sept. 18, 2010). Moonitz reported:
}

In the late 1930's, T.H. Sanders (Harvard), H.R. Hatfield (California), and U. Moore (Yale) prepared A Statement of Accounting Principles ... which would be useful in the clarification and improvement of corporate accounting and of financial reports issued to the public . . . For all practical purposes, the report was ignored both by practitioners and by academicians despite the fact that the report mirrored quire faithfully the best practice of the day.

Id.

16915 U.S.C. $\iint 77 \mathrm{~s}(\mathrm{a}), 78 \mathrm{~m}(\mathrm{~b})(1)$ (2006).

170 Nat'l Sur. Corp. v. Lybrand, 9 N.Y.S.2d 554, 563 (1939).

${ }^{171} I d$. 
Regretfully, the development of accounting standards began to diverge from the Congressional intent of fair disclosure. ${ }^{172}$ Congress envisioned a disclosure system where "[a] balance sheet... gives an intelligent idea of the assets and liabilities of the issuer and a profit and loss statement [and] . . gives a fair picture of its operations." ${ }^{173}$ However, the accounting profession quietly began migrating away from principles-based standards which emphasized "fair" disclosure in favor of rules-based standards, which emphasized mechanical compliance. ${ }^{174}$ The reason for this change in financial reporting philosophy was to address the accountant's increasing concern with personal liability. ${ }^{175}$ Certifying financial statements as being in accordance with GAAP no longer meant that the financial statements were fairly presented in accordance with GAAP. ${ }^{176}$ Rather, it meant that the financial statements were technically compliant with GAAP. ${ }^{177}$ This subtle but important change in creating accounting standards by private standard setters would eventually spawn the financial disasters that befell the United States at the beginning of the 21 st century. ${ }^{178}$

Why has the SEC consistently failed to create sound accounting standards? ${ }^{179}$ The SEC has the indisputable authority to legislate accounting rules. ${ }^{180}$ Both the

172 H.R. Report No. 73-85, at 7 (1933), reprinted in 1 Federal SECurities Laws: Legislative HISTORY 1933-1982, at 144 (1983).

${ }^{173} I d$.

${ }^{174}$ Id.; see also Securities \& Exchange Commission, Study Pursuant to Section 108(d) of the SarbanesOxley Act of 2002 on the Adoption by the United States Financial Reporting System of a PrinciplesBased Accounting System (July 25, 2003), available at http://www.sec.gov/news/ studies/principlesbasedstand.htm [hereinafter SEC Study].

175 See SEC Study, supra note 174.

176 H.R. Report No. 73-85, at 7 (1933), reprinted in 1 Federal SECurities Laws: Legislative HISTORY 1933-1982, at 144 (1983).

177 Auditing STANDARDs BOARD, supra note 7, at 571.

178 See James J. Park, Assessing the Materiality of Financial Mistatements, 34 J. CORP. L. 513, 554 (2009). Enron's abuse of Special Purpose Entities led to inflation of Enron's income "by \$28 million in 1997 (of $\$ 105$ million total), by $\$ 133$ million in 1998 (of $\$ 703$ million total), by $\$ 248$ million in 1999 (of $\$ 893$ million total), and by $\$ 99$ million in 2000 (of $\$ 979$ million total)." Id.

179 See Sec. \& Exch. Comm'n v. Nacchio, No. 05-CV-00480-MSK-CBS, 2009 WL 211511, at *6 (D. Colo. Jan. 29, 2009) (citing deposition testimony in which SEC witnesses conceded that the agency relied on private sector standard setting bodies (e.g., the Financial Accounting Standards Board ('FASB') established GAAP relating to the transaction at issue, indefeasible rights of use, and swap transactions)). 
Securities Act and the Exchange Act authorize the SEC to prescribe "the methods to be followed in the preparation of" accounts for filings that companies are required to submit to the SEC. ${ }^{181}$ The concept of a free and ordered market carries with it the necessary implication that both the buyer and seller are acting in the exercise of an informed judgment in arriving at a fair price. Insofar as the judgment of either party is distorted by false, inaccurate, or incomplete financial information, the price will be distorted, and the markets will fail to reflect the normal operation of the law of supply and demand.

The American national economy has evolved from one where investors sell goods with an intrinsic and immediately verifiable value, to an economy where vast sums of wealth are created by the sale and exchange of securities, which do not have intrinsic and immediate value. Instead, securities derive their value from assets reported through financial statements. One would reasonably expect the SEC, in the interest of national economic stability, to regulate the creation of accounting standards actively with the objective of ensuring certainty and confidence in the capital markets. Instead, American accounting standards are closer to where they were during the Great Depression when an observer stated:

$[\mathrm{W}]$ e have drifted into a gambler's civilization, in which men are no longer inclined to invest their money in proven and honest business; but, believing they can make more money in the negotiation and sale of securities, sometimes upon a margin and upon a basis of gambling, our whole financial system has taken on the psychology of gambling instead of honest methods of ... industry." ${ }^{\text {,182 }}$

Is the "gambler's civilization" unstated SEC economic policy?

\section{Government or Private Standard Setter?}

\section{A. SEC Structure}

A related question relevant to the creation of accounting standards is "who should be creating accounting standards?" This question has been a point of

\footnotetext{
18015 U.S.C. $\iint 77 \mathrm{~s}, 78 \mathrm{~m}(\mathrm{~b})(1)$ (2006).

${ }^{181} I d$.

18273 CONG. REC. H2914 (daily ed. May 5 1933) (statement of Rep. Greenwood), reprinted in 1 FEDERAL SECurities LAws, LegisLative History 1933-1982, at 172 (1983).
} 
continuing controversy. ${ }^{183}$ Is private industry the preferred standard setter, or is government? Or is something external to the U.S. markets preferred? ${ }^{184}$ The debate concerning the creation of accounting standards has been present since the nineteenth century. ${ }^{185}$ At first blush, it appears that Congress answered this question when it created the SEC in 1934 and empowered it to establish accounting standards. ${ }^{186}$

The SEC consists of five divisions: the Division of Corporate Finance, ${ }^{187}$ the Division of Enforcement, ${ }^{188}$ the Division of Investment Management, ${ }^{189}$ and the Division of Trading and Markets. ${ }^{190}$ Each Division is charged with a unique set of

183 See generally Lawrence A. Cunningham, A Prescription to Retire the Rhetoric of "Principles-Based Systems" in Corporate Law, Securties Regulation, and Accounting, 60 VAND. L. REV. 1411 (2007) (addressing this question).

184 The U.S. is currently examining whether the International Accounting Standards Board should determine accounting standards for use within the United States. See Roadmap for the Potential Use of Financial Statements Prepared in Accordance with International Financial Reporting Standards by U.S. Issuers, Comments on Proposed Rule Release No. 33-8982 (Mar. 20, 2009). A study of International Financial Reporting Standards ("IFRS") is beyond the scope of this article. But see Cunningham, supra note 183; Robert H. Herz \& Kimberly R. Petrone, International Convergence of Accounting Standards -- Perspectives from the FASB on Challenges and Opportunities, $25 \mathrm{Nw}$. J. INT'L L. \& BUS. 631 (2005). The U.S. is presently studying the feasibility of adopting IFRS as a financial reporting system, and there is a healthy debate in the U.S. concerning the benefits and detriments of adopting IFRS as a reporting standard.

185 EDWARDS, supra note 47, at 109.

18615 U.S.C. $\int 78 \mathrm{~m}(\mathrm{~b})(1)$ (2006).

187 Securities \& Exchange Commission, Division of Corporation Finance, http://www.sec. gov/divisions/corpfin.shtml (last visited Sept. 19, 2010).

188 "The Division of Enforcement investigates possible violations of securities laws, recommends Commission action when appropriate, either in a federal court or before an administrative law judge, and negotiates settlements." Securities \& Exchange Commission, Division of Enforcement, http://www.sec.gov/divisions/enforce.shtml (last visited Sept. 19, 2010).

189 "The Division of Investment Management regulates investment companies (such as mutual funds, closed-end funds, UITs, ETFs, and interval funds), including variable insurance products, and federally registered investment advisers." Securities \& Exchange Commission, Division of Investment Management, http://www.sec.gov/divisions/investment.shtml (last visited Sept. 19, 2010).

190 “The Division of Trading and Markets establishes and maintains standards for fair, orderly, and efficient markets. The Division regulates the major securities market participants, including brokerdealers, self-regulatory organizations (such as stock exchanges, FINRA, and clearing agencies), and 
responsibilities designed to supervise and enforce compliance with the securities laws.

The mission of the Division of Corporation Finance is:

$[\mathrm{T}] \mathrm{o}$ see that investors are provided with material information in order to make informed investment decisions - both when a company initially offers its stock to the public and on a regular basis as it continues to give information to the marketplace. The Division also provides interpretive assistance to companies on SEC rules and forms and proposes new and revised rules to the Commission. ${ }^{191}$

The SEC policy of working in collaboration with the business community was shaped during the SEC's initial years. ${ }^{192}$ In a speech delivered by the SEC's first Chairman, Joseph Kennedy, he stated that:

Paralyzing regulations are thoroughly unAmerican. No important rule or regulation will be adopted without consultation with representatives of any class which might be affected thereby. No regulation will be passed which is not reasonably adapted to the accomplishment of the statutory objective. No promulgation by the Commission, I pledge you, shall involve any undue risk of embarrassment, expense, or liability to business. ${ }^{193}$

This statement foreshadowed what was to become the SEC's operating norm in the coming years.

The SEC faced considerable resistance from the business community as it began its task of administering the newly enacted securities laws. In an attempt to make the new securities laws more palatable to the business community, the SEC indicated that "[e]ffort has been made as far as possible to make the accounting

transfer agents." Securities \& Exchange Commission, About the Division of Trading and Markets, http://www.sec.gov/divisions/marketreg/mrabout.shtml (last visited Sept. 19, 2010).

191 Securities \& Exchange Commission, Division of Corporation Finance, http://www.sec.gov/ divisions/corpfin.shtml (last visited Sept. 19, 2010).

192 Joseph P. Kennedy, Chairman, Securities \& Exchange Commission, Chicago Speech, Speech before the Union League Club of Chicago 1 (Feb. 8, 1935), available at http://www.sec.gov/news/speech/1935/020835kennedy.pdf.

${ }^{193} I d$. 
requirements for registration of securities of going concerns under the Securities Act consistent with those for the registration of securities on the exchanges." 194 This expressed desire to achieve parity in accounting with the exchanges profoundly influenced future action by the SEC. ${ }^{195}$ Moreover, the SEC added that:

[It] has carefully avoided requiring uniformity of accounting either as to matters of classification or as to matters of principle. It has provided for a degree of uniformity in methods of reporting[], the results of business operations and the financial condition of the business, but even here its requirements are not rigid. ${ }^{196}$

Concern for guidance and uniformity in accounting standards has been voiced since the enactment of the Securities Act and the Exchange Act. ${ }^{197}$ The SEC originated its philosophy of yielding to the accounting profession in establishing accounting standards during its formative years. ${ }^{198}$ The SEC stated that "[s]ince sound and informative accounting statements are basic under each of these Acts, the part played by the accountant in their administration is extremely important[] and much dependence is placed upon the results of [the accountant's] work." 199 The SEC added that "[s]ince most of the required financial statements must be certified by independent public or independent certified public accountants, the practical effect ... is to leave the responsibility for the way in which the presentation is to be

194 Mathews, supra note 135, at 3. Black's Law Dictionary defines "going concern" as "[a] commercial enterprise actively engaging in business with the expectation of indefinite continuance." BLACK'S LAW DiCTIONARY 113 (8th ed. 2004).

195 Financial accounting Standards Board, Special Report: The Framework of FinANCIAL ACCOUNTING CONCEPTS AND StANDARds 14 (1998) [hereinafter FASB SPECial REPORT].

196 Mathews, supra note 135, at 3.

197 In 1938, William O. Douglas, Supreme Court Justice, wrote to William Wernts, Chief Accountant of the SEC, and inquired about a previous discussion he had with the Department of the Treasury "relative to the possibility of the Treasury and the SEC working out greater uniformity in accounting practices." Letter from William O. Douglas, Supreme Court Justice, to William Wernts, Chief Accountant, Securities \& Exchange Commission (Aug. 2, 1938), available at http://c0403731. cdn.cloudfiles.rackspacecloud.com/collection/papers/1930/1938_0802_Douglas_114.pdf.

${ }^{198}$ FASB SPECIAL REPORT, supra note 195, at 14.

199 Blough, supra note 165, at 1. 
made, with certain expressed limitation, to the certifying accountant."200 This concession by the SEC all but assured the accounting profession that the SEC will not take an active role in creating accounting standards. ${ }^{201}$

\section{B. History of Private Standard Setters}

In 1939, the formation of the Committee on Accounting Procedure ("CAP"), a private organization of accountants, marked the first attempt by a national group of accountants to undertake the task of creating and organizing uniform standards. ${ }^{202}$ The CAP is also credited as being the first organization to use the term, "Generally Accepted Accounting Principle." 203 The CAP was in existence from 1939 to $1959 .^{204}$ During its tenure, it issued 51 Accounting Research Bulletins ("ARB") ${ }^{205}$ designed to give the accounting profession guidance when recording financial transactions. ${ }^{206}$ The CAP was dissolved in 1959 and replaced by its successor, the Accounting Principles Board (“APB”). ${ }^{207}$

The APB, another private member national organization, existed from 1959 to $1973 .^{208}$ The stated objectives of the APB were "[(a)] to advance the written expression of accounting ... principles, ... [(b)] to determine appropriate practice[s, ] and $[(\mathrm{c})]$ to narrow the areas of difference and inconsistency in practice."209 During its tenure, the APB issued 31 accounting pronouncements, known as APB Opinions,

${ }^{200} I d$. at 2.

${ }^{201}$ FASB SPECIAL REPORT, supra note 195, at 14.

202 American Institute of Certified Public Accountants, Accounting Research and Terminology Bulletins 5 (Final ed. 1961) [hereinafter AiCPA Bulletins].

203 American Institute of Certified Public Accountants, Examination of Financial StATEMENTS By Independent Public ACCOUNTANTS (1936).

204 AICPA BuLLETINS, supra note 202, at 2.

205 The accounting statements were issued under the nomenclature Accounting Research Bulletin (“ARB”).

206 Id. Accounting Research Bulletin No. 43 is a consolidation of the prior ARBs. It is captioned, "Restatement and Revision of Accounting Research Bulletins" (September 1, 1959), and includes a table illustrating the action taken (e.g. amended, deleted, etc.) on previously issued statements. See Financial Accounting Standards Board, Original Pronouncements 37 (2005).

207 AICPA BuLLETINS, supra note 202, at 2.

${ }^{208}$ FASB SPECIAL REPORT, supra note 195, at 31.

${ }^{209} I d$. at 32 . 
regarding the suggested treatment of financial transactions. ${ }^{210}$ However, the APB met considerable resistance from the accounting profession because of certain positions which it proposed. ${ }^{211}$ In 1973, the APB was dissolved and replaced with the Financial Accounting Standards Board ("FASB"). ${ }^{212}$

The SEC recognizes the FASB as the principal standard-setting body for GAAP such that any FASB pronouncements constitute GAAP. ${ }^{213}$ Congress would eventually codify the SEC's authority to rely on private standard setters in $2002 .^{214}$ Since inception, FASB has issued 168 Financial Accounting Statements ("FAS") establishing GAAP. FAS 168, issued in June 2009, is the most recent accounting

210 Id. at 45.

211 Id. The APB and the SEC were unable to operate completely independently of the U.S. government. According to the SEC, "[t]he over-all [sic] record of the APB was a reasonably good one, but it seems likely that a smaller full-time body directly in control of its research holds promise of more success." John C. Burton, Chief Accountant, Securities \& Exchange Commission, General Thoughts on the Accounting Environment and Specific Thoughts on Accounting for Lease Financing, Speech before the AGA-EEI Accounting Conference 2 (May 7, 1973), available at http://www.sec.gov/news/speech/1973/050773burton.pdf.

212 William W. Bratton \& Lawrence A. Cunningham, Treatment Differences and Political Realities in the GAAP-IFRS Debate, 95 VA. L. REV. 989, 999 (2009) ("The FASB came into existence thirty-five years ago as the result of an ad hoc process looking toward the establishment of a viable standard setter under private auspices. The accountants' professional organization, the American Institute of Certified Public Accountants ("AICPA"), took the lead, with input from organizations and individuals representing management and the financial sector. The organizers had a high-powered incentive. They wanted a responsive standard setter without ceding territory to a federal agency, which in those days was associated with domination by progressive, anti-corporate types.”).

213 See Securities \& Exchange Commission, Accounting Release No. 150, at 1 (1973), available at http://c0403731.cdn.cloudfiles.rackspacecloud.com/collection/papers/1970/1973_1220_SECAccou nting.pdf.

214 See 15 U.S.C. $\$ 77 \mathrm{~s}(\mathrm{~b})(2006)$. Section 77s provides in relevant part:

[T] he Commission may recognize, as "generally accepted" for purposes of the securities laws, any accounting principles established by a standard setting body . . . that is organized as a private entity[, . . . has . . . a board of trustees . . . serving in the public interest, ... has adopted procedures to ensure prompt consideration, by majority vote of its members, of changes to accounting principles ... and that the Commission determines has the capacity to assist.

Id. 
standard that FASB has issued. It codifies and describes the hierarchy of GAAP. ${ }^{215}$ FASB will not issue future statements. ${ }^{216}$ Instead, FASB "will issue Accounting Standards Updates [(“ASU”)]. The Board will not consider [ASU's] as authoritative in their own right. [ASU's] will serve only to update the Codification." 217 FAS 168 "identifies the sources of accounting principles and the framework for selecting the principles used in the preparation of financial statements." ${ }^{218}$ FAS 168 is an ambitious undertaking and seeks to source the entire hierarchy of GAAP in one place. $^{219}$ Furthermore, FAS 168 introduces a new aspect to accounting standards, namely, the concept of authoritative and nonauthoritative GAAP. ${ }^{220}$ FAS 168 permits management and accountants to refer to both authoritative and nonauthoritative GAAP when preparing financial statements. ${ }^{221}$

Despite the SEC's conciliatory stance in regulating accounting standards, the accounting profession has demonstrated that it will aggressively object to the creation of new standards or SEC enforcement actions. The case of Arthur Andersen v. Securities Exchange Commission ("Andersen") illustrates the tension that arises whenever the SEC enacts new rules. ${ }^{222}$

215 See FAS No. 168, supra note 53.

${ }^{216} I d$. at Summary.

${ }^{217} I d$.

${ }^{218} I d$. at 92.

${ }^{219} I d$. at 93 .

${ }^{220} \mathrm{Id}$. at 10 ("Sources of nonauthoritative accounting guidance and literature include, for example, practices that are widely recognized and prevalent either generally or in the industry, FASB Concepts Statements, [AICPA] Issues Papers, International Financial Reporting Standards of the International Accounting Standards Board [IASB], pronouncements of professional associations or regulatory agencies, Technical Information Service Inquiries and Replies included in AICPA Technical Practice Aids, and accounting textbooks, handbooks, and articles."').

221 See Financial Accounting Standards Board, The FASB Accounting Standards Codification Q\&A (July 9, 2009), http://www.picpa.org/content/files/Documents/Q\&A-FASB-ASC-FINAL.pdf (“The new standard essentially reduces the GAAP hierarchy to two levels: one that is authoritative (in the codification) and one that is not (not in the codification)."').

222 Arthur Andersen \& Co. v. Sec. \& Exch. Comm'n, No. 76C2832, 1976 WL 826 (N.D. Ill. Sept. 3, 1976). 
The issue in Andersen was whether the SEC had the authority to issue two disputed Accounting Series Releases ("ASR"). ${ }^{223}$ They were ASR 150 and ASR 177. ${ }^{224}$ ASR 150 provided that "standards and practices promulgated by the FASB in its Statements and Interpretations will be considered by the Commission as having substantial authoritative support, and those contrary to such FASB promulgations will be considered to have no such support." 225 ASR 177 "adopted a rule amending Instruction $\mathrm{H}(\mathrm{f})$ of Form 10-Q",26 to require "that when a business enterprise changes an accounting principle or rule previously followed, the first quarterly financial report filed thereafter with the SEC must include a letter from the firm's independent accountant indicating whether the change to the alternate principle is preferable." 227

The plaintiff, Arthur Andersen, sought an injunction to restrain the SEC from implementing the disputed ASRs. ${ }^{228}$ Arthur Andersen argued that the SEC violated "the requirements of the Administrative Procedure Act, ... the SEC's own rule-making regulations, . . . and generally the Constitution and laws of the United States."229 The District Court denied Arthur Andersen's motion for preliminary injunction by reasoning under ASR 150 that the "SEC has said no more than it will henceforth, in making its long-standing inquiry into whether a financial statement has been prepared in accord with accepted accounting principles, apply and look to

${ }^{223}$ Id. at *2. The 1944 SEC Annual Report states that "Accounting Series releases constitute the Commission's principal instrument, other than its formal decisions and reports, for informing the public as to its basic policy in accounting matters." SECURITIES \& EXCHANGE COMMISSION, TENTH ANNUAL REPORT: A TEN YEAR SURVEY 1934-1944 150 (1944).

224 Andersen, 1976 WL 826, at*2.

225 Securities \& Exchange Commission, Accounting Release No. 150, at 2 (1973), available at http://c0403731.cdn.cloudfiles.rackspacecloud.com/collection/papers/1970/1973_1220_SECAccou nting.pdf.

226 Andersen, 1976 WL 826, at *4. Form 10-Q is a form which must be filed on a quarterly basis by public companies with the SEC. Id.

227 Id. at $* 2$.

${ }^{228} I d$. (footnote omitted).

${ }^{229}$ Id. at *1. 
the substantial authoritative support provided by the FASB." ${ }^{230}$ The court added that "the SEC has done no more than state the obvious."

The court rejected Arthur Andersen's argument that Instruction $\mathrm{H}(\mathrm{F})$ under ASR-177 "is arbitrary and capricious because it may prove impossible for an accountant's registrant client to comply with it." ${ }^{\text {"232 }}$ The District Court noted that all ASR-177 "asks is that . . a registrant's accountant state why the registrant has changed from one accepted method or principle of accounting to another. There must be a reason for the change. What harm can flow from articulating it?" ${ }^{233}$

Free Enterprise Fund v. Public Company Accounting Oversight Board ("Free Enterprise Fund") illustrates another example where the accounting profession will aggressively defend its interests. ${ }^{234}$ Free Enterprise Fund challenged the constitutionality of Title I of SOX. ${ }^{235}$ "Congress passed $[\mathrm{SOX}]$ to improve the regulation of accounting firms." 236 The practical effect of Title I of SOX was to convert the accounting profession from a self regulated industry into a regulated industry. ${ }^{237}$ Title I of SOX creates the Public Company Accounting Oversight Board ("PCAOB"). ${ }^{238}$ Additionally, "Title I of the Act established the PCAOB 'to oversee the audit[ing] of public companies that are subject to the securities laws . . in order to protect the interests of investors and further the public interest in the preparation of informative, accurate, and independent audit reports." ${ }^{239}$ Among its designated responsibilities, the PCAOB oversees and sets auditing standards for the accounting

\footnotetext{
${ }^{230} I d$. at $* 3$.

${ }^{231} I d$. at $* 3$.

232 Id. at $* 4$.

${ }^{233} I d$. at $* 5$.
}

${ }^{234}$ Free Enter. Fund v. Pub. Co. Accounting Oversight Bd., 537 F.3d 667 (D.C. Cir. 2008), cert. granted, 129 S.Ct. 2378 (2009).

$235 \mathrm{Id}$. at 668.

236 Recent Case, Free Enter. Fund v. Pub. Co. Accounting Oversight Bd., 537 F.3d 667 (D.C. Cir. 2008), 122 HARV. L. REV. 2267, 2267 (2009).

23715 U.S.C. $\int 7211$ (a) (2006)

238 Id.

239 See KIESO ET AL., supra note 63, at 669. Audit reports must state whether the financial statements are prepared in accordance with generally accepted accounting principles. 
profession. ${ }^{240}$ The issue in this case was whether the creation of the PCAOB violated the Appointments Clause of the United States Constitution and separation of power principles. ${ }^{241}$

The plaintiffs were "a non-profit public interest organization that 'promote[d] economic growth, lower taxes, and limited government . . and . . a a Nevada accounting firm ${ }^{242}$ that were registered with the Board and were subject to an ongoing formal investigation." ${ }^{243}$ The Court of Appeals held that "the Fund's facial challenge to Title I of the Act fails to reveal violations of the Appointments Clause or separations of powers. ${ }^{244}$ The practical effect of a victory for the plaintiffs in this case would have been a return to the era of self regulation by the accounting profession, which was the very problem that led to the enactment of SOX.

\section{What is the Public Interest?}

Scholars have conceptualized two different views about the nature and purpose of professions and their professional associations. These views are:

The "altruistic" approach [that] regards professions as providing services which make a distinctive contribution to the smooth operation of society ... [and] [t]he "cynical" assessment ... that ... [regards] professions [as] groups of individuals pursuing self-interest, striving to convince others of their entitlement to professional recognition and reward, and doing a job which is just enough to satisfy clients and maintain their professional status. ${ }^{245}$

Expecting a private standard setter to advocate for accounting standards, which are in the public interest, is unrealistic when the private standard setter's members depend on satisfying the needs of their clients. Several factors support this assertion.

\footnotetext{
24015 U.S.C. $\int 7211$ (c) (2006). granted, 129 S.Ct. 2378 (2009).

242 The accounting firm is Beckstead and Watts, LLP.

${ }^{243}$ Free Enter. Fund, 537 F.3d at 670.

${ }^{244} I d$. at 685.

${ }^{245}$ EDWARDS, supra note 47, at 276.
}

${ }^{241}$ Free Enter. Fund v. Pub. Co. Accounting Oversight Bd., 537 F.3d 667, 668 (D.C. Cir. 2008), cert. 
First, neither private standard setters, generally, nor accountants, specifically bear a legal duty or responsibility to establish rules that are socially beneficial. ${ }^{246}$ This statement is true despite the Supreme Court's pronouncement in United States vs. Arthur Young \& Co.:

By certifying the public reports that collectively depict a corporation's financial status, the independent auditor assumes a public responsibility transcending any employment relationship with the client. The independent public accountant performing this special function owes ultimate allegiance to the corporation's creditors and stockholders, as well as to investing public. This "public watchdog" function demands that the accountant maintain total independence from the client at all times and requires complete fidelity to the public trust. $^{247}$

Second, the proper role for private organizations is to improve and facilitate markets to permit continued growth and innovation. ${ }^{248}$ It is not to assume the role of a public caretaker. Managing and overseeing the public welfare is a governmental function, not a private organizational function. History bears out that the membership of the private standard setter will voice opposition and exert considerable pressure if a particular pronouncement will have an adverse impact

246 See, e.g., Ultramares Corp. v. Touche, 174 N.E. 441 (N.Y. 1931). Ultramares is the touchstone case examining accountants' liability. The plaintiff alleged that the accountants acted negligently and fraudulently when certifying a company's financial statements. The plantiff hired the firm of public accountants "to prepare and certify a balance sheet exhibiting the condition of [another] business as of December 31, 1923." Id. at 442. The plaintiff suffered financial losses as the result of lending money on the strength of the "balance sheet certified by the public accountants." Id. at 443. Justice Cardozo, writing for the majority reversed the trial court's judgment against the defendants reasoning that "[i]f liability for negligence exits, [then] a thoughtless slip or blunder, the failure to detect a theft or forgery beneath the cover of deceptive entries, may expose accountants to a liability in an indeterminate amount for an indeterminate time to an indeterminate class." Id. at 444.

${ }^{247}$ United States v. Arthur Young \& Co., 465 U.S. 805, 817-18 (1984) (emphasis in original).

248 See, e.g., Frank H. Easterbrook \& Daniel R. Fischel, Mandatory Disclosure and the Protection of Investors, 70 VA. L. REV. 669, 688 (1984) ("Accountants . . . serve as intermediaries . . . [T]o the extent accountants agree on a common language, they serve the function of standardizing (reducing the costs of) any amount of disclosure. Accountants spread over all firms the costs of creating and maintaining the standard language. Of course accountants may face pressures from individual firms to misuse their language, or they may be unable to agree on a common language at all.’'). 
upon clients. ${ }^{249}$ The belief that the ultimate motivation of the membership of any private standard setter is self-interest, and not public duty, is reasonable. To believe otherwise, is foolhardy.

Third, there is a disturbing trend in accounting standards. Originally, accounting standards were restrictive in the sense that they were conservative and sought to minimize the overstatement of values. ${ }^{250}$ Accounting standards at the time when the Securities Act and the Exchange Act came into effect were entirely different from current GAAP standards. Accounting standards used during the early period of the Securities Act and the Exchange Act were conservative in posture. ${ }^{251}$

Recently however, there has been a marked shift away from standards which follow the principle of conservatism ${ }^{252}$ to standards that follow the fair value principle. ${ }^{253}$ Fair value accounting results in artificial increases to the value of the company and its portfolio value to shareholders. Although no reasonable investor will object to increased portfolio values, two immediate problems arise with this approach. One problem is that value creation activities should be done through legitimate company operations involving actual growth and market opportunities.

${ }^{249}$ Consider for example, the opposition raised by companies and the accounting profession during the debates for stock option expensing.

250 See KIESO ET AL., supra note 63, at 423 (For example, the lower-of-cost-or-market inventory method is a conservative approach to inventory valuation.); see also AMERICAN INSTITUTE OF PUBLIC Accountants, Committee on Accounting Procedure, Accounting Research Bulletin No. 43, at 6016 (1953) ("The rule of cost or market, whichever is lower is intended to provide a means of measuring the residual usefulness of an inventory expenditure.”).

251 See Financial Accounting Standards BoArd, Statement of Financial Accounting CONCEPTS NO. 2, at 68 (2002) ("Frequently, assets and liabilities are measured in a context of significant uncertainties. Historically, managers, investors, and accountants have generally preferred that possible errors in measurement be in the direction of understatement rather than overstatement of net income and net assets. This has led to the convention of conservatism.”').

${ }^{252} I d$.

253 See Financial Accounting Standards BoArd, Statement of Financial Accounting STANDARDS NO. 107, at 4 (1991) ("An entity shall disclose, either in the body of the financial statements or in the accompanying notes, the fair value of the financial instruments for which it is practicable to estimate that value."); see also FinANCIAL ACCOUNTING STANDARDS BOARD, Statement of Financial AcCounting StAndards No. 133, at 1 (1998) ("Fair value is the most relevant measure for financial instruments and the only relevant measure for derivative instruments. Derivative instruments should be measured at fair value.”) (emphasis omitted). 
Value creation should not occur through the niceties of accounting techniques which are now deployed by companies as if they were intangible assets. Another problem is that the further the accounting standards stray into the concept of fair value accounting, and away from the notion of conservatism, the greater the likelihood that company management will manipulate measurements and values, which will ultimately steepen the decline in the event of another financial meltdown. ${ }^{254}$ Fair value accounting has merit. However, the decision of whether to pursue it should be that of a federal entity with a public interest, not a private standard setter lacking a positive public duty.

\section{GAAP'S INFLUENCE ON THE LAW}

\section{A. Federal Level Influence}

Government intervention in establishing accounting standards is reasonable when one considers that GAAP has expanded beyond the domain of securities regulation. Congress has adopted GAAP as the preferred measurement standard, not only within the securities law context, but in other areas of federal regulation. ${ }^{255}$ For instance, at the federal level, the Department of Agriculture requires that an entity's accounting records comply with GAAP before the entity is eligible to receive federal funds; ${ }^{256}$ federal banking legislation requires that a bank calculate its "core capital" in accordance with GAAP; $;$ federal legislation also requires that all reporting of Troubled Asset Relief Program (TARP) ${ }^{258}$ fund activities be in

\footnotetext{
254 Critics of fair value accounting point to the fact that the fair value determination is a subjective standard and that companies will be involved in "gains trading" as they cherry pick their asset reporting to maximize the company value. See KIESO ET AL., supra note 63, at 860-61.
}

255 GAAP's reputational influence, be it real or perceived, is akin to the Good Housekeeping seal of approval and has garnered the favor of our legislators.

256 See, e.g., 7 U.S.C. \2008j(e)(3)(F) (2008) (For the National Sheep Industry Improvement Center " $[\mathrm{t}] \mathrm{o}$ be eligible to receive amounts from the Fund, [it] must agree to account for the amounts using generally accepted accounting principles.”).

25712 U.S.C. \$4502(7) (2008) (“The term 'core capital' means, with respect to an enterprise, the sum of the following ... as determined in accordance with generally accepted accounting principles.").

258 Emergency Economic Stabilization Act of 2008, Pub. L. No. 110-343, 122 Stat. 3765 (2008)(codified at 12 U.S.C. SS 5201-5261). 
accordance with GAAP, ${ }^{259}$ and federal legislation regarding American Indian tribe reporting requires GAAP-compliant statements to retain federal benefits. ${ }^{260}$ GAAP bears directly upon the substantive legal rights of persons in areas beyond securities regulations, albeit with no legislative or administrative guidance. ${ }^{261}$

\section{B. State Level Influence}

The argument for government intervention strengthens when one considers that GAAP has also been influential at the state level. Many state governments have incorporated GAAP in state legislation as the standard of measurement for financial transactions. For example, state legislatures in Delaware, ${ }^{262}$ New York, ${ }^{263}$ Illinois $^{264}$ and California, ${ }^{265}$ have all adopted GAAP in their respective legislation. The implication is that GAAP will provide legislation with a fair degree of certainty in its

25912 U.S.C. \$5226(b)(1) (2008) ("The TARP shall annually prepare and issue to the appropriate committees of Congress and the public audited financial statements prepared in accordance with generally accepted accounting principles.”).

260 See 25 U.S.C. $\int 3304$ (2008) (“The Secretary may revoke the eligibility of an Indian tribe . . if such tribe ... fails to submit to the Bureau an annual financial statement that reports revenues and expenditures determined by use of an accounting system, established by the tribe, that complies with generally accepted accounting principles.").

261 Private parties can agree on how to measure rights and responsibilities through a contract. However, when a system of measurement has a broad public impact, government intervention becomes necessary to help determine the underlying rights and responsibilities of parties, both of which are relying upon a system of measurement which was created without either party's expressed mutual assent.

262 Del. Code AnN. tit. 8, \503 (2010) ("Interests in entities which are consolidated with the reporting company shall be included within 'total assets' and 'total gross assets' at a value determined in accordance with generally accepted accounting principles.”).

263 N.Y. BANKING $\$ 651$ (McKinney 2003) (providing in relevant part that “[e]very licensee shall at all times maintain permissible investments having (i) a market value, computed in accordance with generally accepted accounting principles, ... or (ii) a net carrying value, computed in accordance with generally accepted accounting principles").

264760 ILl. COMP. STAT. 15/9 (1992) ("Business and farming operations. (a) If a trustee uses any part of the principal in the operation of a business or, except as provided in subsection (b), an agricultural or farming operation, including the raising of animals or the operation of a nursery, the net profits and losses shall be computed in accordance with generally accepted accounting principles.”).

265 CAL. Gov. Code $\int 8880.41$ (West 2010) ("The director shall make and keep books and records that accurately and fairly reflect each day's transactions ... so as to permit preparation of financial statements in conformity with generally accepted accounting principles.”). 
enforcement. GAAP influences state corporation statutes, trust and estates law, banking law, commercial law, and non-profit law. ${ }^{266}$

GAAP also influences state level litigation. Peco Energy Company $v$. Commonwealth of Pennsylvania, ("Peco") ${ }^{267}$ is an example of this influence. In Peco, the dispute between the parties centered on the interpretation of "cost" for purposes of a tax computation under the Public Utility Realty Tax Act ("PURTA"). ${ }^{268}$ The taxpayer, Peco Energy Company ("Peco Energy") "allege[d] that the plain language of [the statute] indicate[d] that the cost to be used is the cost 'as shown on the books of account of a public utility." ${ }^{269}$ Peco Energy contended that the meaning of the term "cost" included a deduction for asset impairment which is in accordance with GAAP. ${ }^{270}$ However, the Commonwealth of Pennsylvania argued that the term "cost" means only "original cost" and does not include a deduction for asset impairment. ${ }^{271}$ The difference in interpretation would directly affect Pensylvania's tax revenues. ${ }^{272}$ The Supreme Court of Pennsylvania held for the taxpayer and noted that "the Legislature is presumed to understand that different terms mean different things." 273 Therefore, the Legislature knowingly chose the standard that included a deduction for asset impairment in "cost."274 The Supreme Court of Pennsylvania further reasoned that the taxpayer's position "is born out by the uncontroverted testimony in the expert [accountant's] reports . . . as well as by the actual language of SFAS 71 and 121, ${ }^{275}$ the applicable GAAP standards.

\footnotetext{
Financial Accounting Standards Board").

267 See Peco Energy Co. v. Commonwealth, 919 A.2d 188 (Pa. 2007).

${ }^{268} I d$ at 189.

${ }^{269} \mathrm{Id}$.

${ }^{270} I d$.

${ }^{271} I d$.

${ }^{272} I d$.

${ }^{273} I d$. at 191.

${ }^{274} I d$.

${ }^{275} I d$. at 190.
}

266 People v. Orange County Charitable Servs., 87 Cal. Rptr. 2d 253, 268 (Cal. Ct. App. 1999) (wherein the California Attorney General notes that sections 17510.3 and 17510.4 of the Business and Professions Code require "certain affirmative disclosures by solicitors of donations" and 17510.5 requires that "business records and disclosures be based on GAAP as defined by AICPA and the 
While Congress and state legislatures seem willing to adopt GAAP as a standard, courts have grappled with the application of GAAP and have reached surprisingly conflicting results. Some courts have upheld the application of GAAP, while other courts have rejected it. The inconsistent position taken by courts when interpreting GAAP contributes to the confusion surrounding GAAP. The lack of definitive guidance by the government only exacerbates the state of confusion.

\section{Instances of Cases Accepting GAAP}

The following cases illustrate the willingness of some courts to embrace GAAP as a financial standard. These courts looked to GAAP for guidance in resolving the conflicts before them and in determining the rights of the litigants.

\section{Salant Corporation v. United States}

In Salant Corporation v. United States ("Salant"), ${ }^{276}$ the Court of International Trade ("CIT") issued an opinion sustaining a decision by the U.S. Customs Service ("Customs") to include "fabric waste generated during the manufacturing process of imported shirts" as an element of taxable value. ${ }^{277}$ The Customs office took the position that product waste is a taxable component of the finished good. Specifically, the Customs office argued that product waste ${ }^{278}$ is considered an "assist" under the relevant statute ${ }^{279}$ and, therefore, is to be included in determining the value of the article for custom valuation purposes. ${ }^{280}$ Salant Corporation ("Salant Corp.") objected to this approach by arguing instead that product waste is not an element to

\footnotetext{
${ }^{276}$ Salant Corp. v. United States, 86 F. Supp. 2d 1301 (Ct. Int'l Trade 2000).

277 Id. at 1302. "Prior to 1995, Customs excluded the value of waste and scrap from the value of an assist. In 1995, Customs published, for comment, a notice changing this policy." Matthew T. McGrath \& Robert A. Shapiro, International Legal Developments in Review: 2000 Business Regulation: Customs Law, 35 INT'L LAW 321, 326 (2001).

278 The term "product waste" is also known as shrinkage or slippage.

279 Salant Corp., 86 F. Supp. 2d at 1302 (referring to 19 U.S.C. \$1401a(h)(1)(A) (1994)).

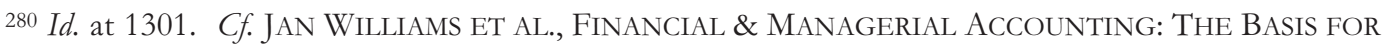
BUSINESS DECISIONS 253 (14th ed. 2008) (noting that "[i]nventory shrinkage refers to unrecorded decreases in inventory resulting from such factors as breakage, spoilage, employee theft, and shoplifting").
} 
be included when valuing an article. ${ }^{281}$ Salant Corp. challenged the determination reached by Customs and brought suit. ${ }^{282}$

The CIT noted that its task was "to determine, based upon the legislative intent and statutory language, whether or not Customs' [sic] interpretation of the assist statute was correct." 283 The court began its analysis by invoking the standard articulated in Chevron, U.S.A., Inc. v. Natural Resources Defense Council, Inc. ("Chevron"), ${ }^{284}$ which instructs:

When a court reviews an agency's construction of the statute which [the agency] administers, [the court] is confronted with two questions. First, always, is the question whether Congress has directly spoken to the precise question at issue. If the intent of Congress is clear, that is the end of the matter; for the court, as well as the agency, must give effect to the unambiguously expressed intent of Congress. If, however, the court determines Congress has not directly addressed the precise question at issue, the court does not simply impose its own construction on the statute, as would be necessary in the absence of an administrative interpretation. Rather, if the statute is silent or ambiguous with respect to the specific issue, the question for the court is whether the agency's answer is based on a permissible construction of the statute. ${ }^{285}$

Finding that Congress had not directly spoken to the precise question at issue, ${ }^{286}$ the CIT determined that this case was a matter of statutory construction and, therefore, decided the case, in part, on that basis. ${ }^{287}$

The CIT reasoned that as the final authority on issues of statutory construction, it employs "the traditional tools of statutory construction" and, therefore. found that "fabric waste comes within the plain meaning of the term

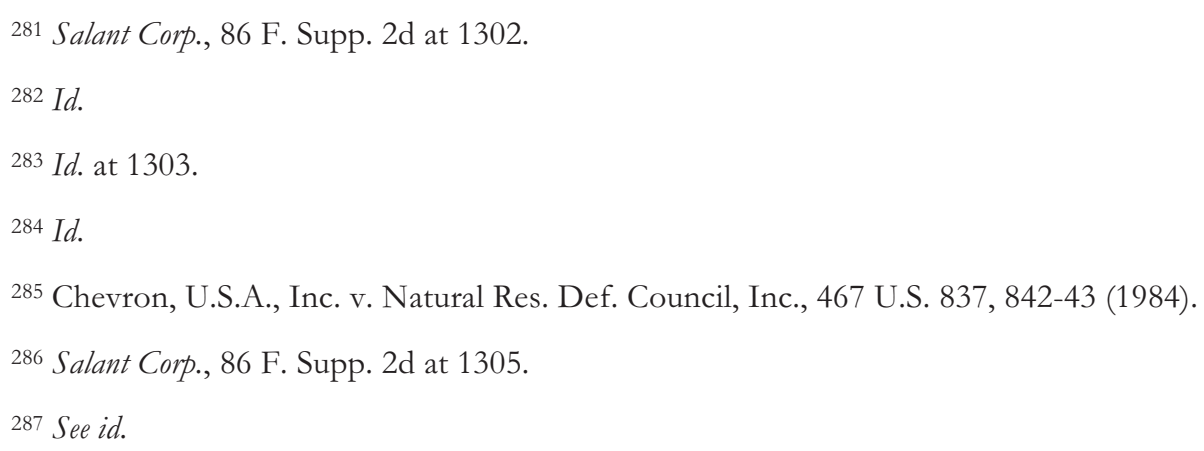


'assist.", 288 The CIT further reasoned that "Congress intended the valuation statute to be interpreted in accordance with Generally Accepted Accounting Principles."289 The CIT stated that Customs "appropriately draws the inference that because inclusion of fabric waste in the definition of an assist is in accordance with GAAP, inclusion of fabric waste in the definition of an assist is in accordance with Congressional intent. ${ }^{290}$ The court ultimately held in favor of the government. ${ }^{291}$ The Congressional preference for GAAP clearly influenced the outcome of this case. $^{292}$

Three observations from Salant are important when considering judicial application of GAAP. First, GAAP has no standard that identifies the accounting treatment for waste. ${ }^{293}$ Waste or its variants are terms that are used by accountants and businessmen to identify product that is not fully utilized when it is taken from its raw and unprocessed stage to its final and manufactured stage. ${ }^{294}$ Therefore, the court's reliance on a GAAP standard in this case is misplaced. Second, the court is confusing financial accounting concepts, which are intended for external users, ${ }^{295}$ with managerial accounting concepts, which are intended for internal users. ${ }^{296}$ Finally, Salant illustrates the challenges courts must face in resolving financial disputes when presumed terms are not clearly defined by statute or administrative guidance.

${ }^{288} I d$. at 1304.

${ }^{289} I d$. at 1306.

${ }^{290}$ Id. at 1301, 1307; cf. IPSCO, Inc. v. United States, 687 F. Supp. 633, 636 n.3 (Ct. Int'l Trade 1988) (" $[\mathrm{F}]$ or purposes of making other determinations under the antidumping laws, Congress has approved use of generally accepted accounting principles.”).

291 Salant Corp., 86 F. Supp. 2d at 1308.

292 See id. at 1307 n.4 (noting with approval that Customs "cite[d] IPSCO, Inc. v. United States").

293 WILLIAMS ET AL., supra note 280, at 253. Inventory shrinkage refers to unrecorded decreases in inventory resulting from such factors as breakage, spoilage, employee theft, and shoplifting.

294 Waste can also be called, shrinkage, slippage or spoilage.

295 An external user of financial statements includes shareholders and creditors.

296 An internal user of financial statements includes directors, officers, and corporate management. 


\section{Continental Web Press, Inc., v. National Labor Relations Board}

Continental Web Press, Inc., v. National Labor Relations Board "“Continental Web Press") is another example where a court embraces the use of GAAP. ${ }^{297}$ After prevailing in litigation, the plaintiff, Continental Web Press, Inc. ("Continental"), sought an award of "roughly $\$ 18,000$ in attorney's fees and related expenses under the Equal Access to Justice Act ["EAJA"] . . . , which allows . . . awards if the government's position is not 'substantially justified." ${ }^{298}$ The National Labor Relations Board ("NLRB") argued against the award. 299 The relevant statute provided that " $[\mathrm{t}] \mathrm{o}$ be entitled to attorney's fees . . . a firm must have either a net worth no greater than $\$ 5$ million or no more than 500 employees." ${ }^{300}$ Unfortunately for the litigants, Congress had not defined the meaning of the term "net worth." 301 Thus, the Court of Appeals reviewed the question of whether Continental's "net worth" was less than $\$ 5$ million. ${ }^{302}$ If so, then Continental would be eligible for a recovery of attorney's fees. ${ }^{303}$

Continental argued that its net worth value was less than $\$ 5$ million. ${ }^{304}$ Continental maintained that a deduction for depreciation expense was permitted. ${ }^{305}$ The depreciation expense deduction brought Continental's net worth below $\$ 5$ million, which made it eligible for attorney's fees. ${ }^{306}$ GAAP allows an expense deduction for depreciation charges. ${ }^{307}$ The National Labor Relations Board

297 Cont'l Web Press, Inc., v. NLRB, 767 F.2d 321, 322 (1985).

${ }^{298} I d$.

${ }^{299} I d$.

${ }^{300}$ Id. (citing 28 U.S.C. $\$ 2412$ (d)(2)(B) (1984)). The statute expired shortly after the court's decision; however, "the expiration does not affect this [decision]." Id.

${ }^{301} I d$. at 323 .

${ }^{302} I d$. at 322.

${ }^{303} \mathrm{Id}$.

304 Id. at 323.

${ }^{305} I d$.

${ }^{306} \mathrm{Id}$.

307 See KIESO ET AL., supra note 63, at 525 (“Companies may use a number of depreciation methods, as follows. Activity method, Straight-line method, Decreasing charge methods [such as the Sum-of-theyears'-digits [and] Declining-balance method.”). 
("NLRB"), however, argued that the depreciation expense should determine Continental's net worth. ${ }^{308}$ The NLRB maintained that the legislative history of the EAJA provided that "[i]n determining the value of assets, the cost of acquisition rather than the fair market value should be used." 309

The Court of Appeals rejected the NLRB's argument. ${ }^{310}$ It reasoned that nothing in the legislative record indicated that Congress meant "the cost of acquisition" to mean the "undepreciated cost of acquisition." 311 Instead, the Court of Appeals noted that "Congress did not define the statutory term, "net worth." 312 Therefore, the Court of Appeals surmised:

It seems a fair guess that if [Congress] had thought about the question, it would have wanted the courts to refer to generally accepted accounting principles. What other guideline could there be? Congress would not have wanted us to create a whole new set of accounting principles just for use in cases under the [EAJA]. ${ }^{313}$

As in Salant, the court in Continental Web Press incorporated into its reasoning a presumption that Congress would have favored a GAAP treatment in this instance. One should note that there is no defined GAAP standard identifying the term "net worth." 314 However, at least one court has defined the term net worth to mean "assets minus liabilities." 315

${ }^{308}$ Cont'l Web Press, 767 F.2d at 322.

${ }^{309}$ Id. at 323 (citing H.R. REP. No. 1418-96 (1980)) (citations omitted).

$310 \mathrm{Id}$. at 324 .

311 Id. at 323 (emphasis added) (internal quotation omitted).

$312 I d$.

${ }^{313}$ Id.; accord Broaddus v. U.S. Army Corps of Engineers, 380 F.3d 162, 167 (4th Cir. 2004) ("We agree with our sister circuits that GAAP applies to EAJA, and net worth is calculated by subtracting total liabilities from total assets.").

314 See KIESO ET AL., supra note 63, at 134 ("What should be included in net income has been a controversy for many years."); see also EDWARDS, supra note 47, at 77-79 (discussing early profit calculations) ("The Roman agricultural writer Columella (circa 60 AD) made an estimate of the profits to be derived from vine growing and compared it with the return which could be obtained by instead investing the money at $6 \%$.").

315 See Ramco Oil \& Gas, Ltd. v. Anglo Dutch (Tenge), L.L.C., 171 S.W.3d 905, 915 (2005) ("While determining "net worth" under GAAP may be quite complicated and may involve different 


\section{Instances of Cases Rejecting GAAP}

The lack of guidance by the federal government in defining GAAP can give unrestrained and contrasting interpretations of a transaction. Inconsistent application of GAAP has created uncertainty in compliance and enforcement efforts by the public and regulators. At times, GAAP is accepted by the courts; at other times, it is rejected. One court stated: "GAAP does not constitute legal authority for the propriety of a given accounting method; rather, GAAP is merely a nondispositive statement of customary accounting practices." ${ }^{316}$ The following cases reflect the tension created by such a "nondispositive" approach.

1. Thor Power Tool Co. v. Commissioner

Thor Power Tool Co. v. Commissioner ("Thor") ${ }^{317}$ is the seminal case illustrating a rejection of GAAP. Thor Power Tool Co. ("Thor") manufactured "hand-held power tools, parts and accessories and rubber products." ${ }^{318}$ Thor's tools required between 50 to 200 parts each. ${ }^{319}$ Manufacturers like Thor require a sizeable product inventory to continue production. ${ }^{320}$ Thor's management adopted a policy of maintaining "liberal quantities" of inventory items in order to reduce inventory stock-outs and avoid "delays in filling orders." "T21 Thor used the lower of cost or market inventory method (LCM) to calculate inventory costs, ${ }^{322}$ an inventory method approved by GAAP.

In 1960, Thor's management initiated the practice of writing down inventory costs at $10 \%$ per year so that the entire cost of the product was written off over a 10 year period. ${ }^{323}$ Four years later, a new management team was installed. ${ }^{324}$ The new

considerations ..., the unambiguous meaning of this term is the difference between total assets and total liabilities determined in accordance with GAAP.").

316 Doyon, Ltd. v. United States, 42 Fed. Cl. 175, 185 (Fed. Cl. 1998).

317 Thor Power Tool Co. v. Comm’r, 439 U.S. 522 (1979).

$318 \mathrm{Id}$. at 525.

${ }^{319} I d$.

320 See id.

${ }^{321} I d$. at $525-26$.

$322 \mathrm{Id}$. at 525.

$323 \mathrm{Id}$. at 526.

${ }^{324}$ Id. 
management determined that the recorded inventory values were overstated. ${ }^{325}$ As a result, Thor adopted a new inventory policy and recalculated its inventory values. ${ }^{326}$ The new inventory policy, another GAAP-approved method, resulted in a loss in inventory value to Thor. ${ }^{327}$

Thor's approach in calculating the new inventory values was consistent with GAAP. ${ }^{328}$ Thor reported these new values and the resulting inventory write-off on its tax return. ${ }^{329}$ On audit, however, the Internal Revenue Service ("IRS") rejected Thor's inventory write-off deduction. ${ }^{330}$

Thor arranged the inventory write-downs into three categories. ${ }^{331}$ Deductions for the first two categories of inventory were allowed because Thor scrapped or sold these items at reduced prices. ${ }^{332}$ However, the IRS disallowed deductions for the third category because Thor failed to "scrap" these items despite reducing the inventory value. ${ }^{333}$ Instead, Thor retained the scrapped inventory on hand and held it out for sale at regular prices. ${ }^{334}$ Thor based its justification for determining the inventory write-down for this third category on two methods. ${ }^{335}$ First, Thor justified its inventory write-down on its president's 20 years of industry experience. ${ }^{336}$ He rationalized that a 20 -year write-down period was proper in this

${ }^{325} \mathrm{Id}$.

326 See id. at 526-27.

327 See id.

${ }^{328} I d$. at 530. Thor had calculated its inventory value using the "lower of cost or market" method, but it changed to the current "net realizable value" method. See id.

329 See id.

${ }^{330} \mathrm{Id}$.

${ }^{331} I d$. at 526-27.

${ }^{332} \mathrm{Id}$. The first group of inventory items consisted of obsolete, damaged or defective inventory items with a value of $\$ 2.75$ million dollars; Thor scrapped most of these items. Id. at 526 . The second group of inventory items consisted of inventory parts for unsuccessful products; Thor sold most of these at reduced prices. Id. at 526-27.

333 Id. at 529-30. The third group consisted of "excess inventory" that Thor "did not immediately scrap ... or sell ... at reduced prices." Id.

${ }^{334}$ Id. at 529.

$335 \mathrm{Id}$. at 527.

${ }^{336} I d$. at 528 n. 5 . 
instance. ${ }^{337}$ Second, Thor defended its decision to write down the inventory based on its naked assertion of a "best estimate." "338

Thor argued that its deduction for an inventory write-off expense was based on GAAP, and therefore, the deduction should be allowed. ${ }^{339}$ The IRS countered by stating that compliance with GAAP was not the sole measure of financial performance. ${ }^{340}$ The IRS argued that, consistent with Section 446(b) of the Internal Revenue Code ("Tax Code"), the method used in calculating income or expense must "clearly reflect income." 341 The Tax Court agreed with the IRS's position. ${ }^{342}$ The Tax Court held that, consistent with the Tax Code and Regulations, a determination of income must clearly reflect income. ${ }^{343}$ The Tax Court found that the excess inventory write-down did conform with GAAP. ${ }^{344}$ However, the Tax Court rejected Thor's reliance on GAAP by stating that "conformance with GAAP is not enough." "345 The Court recognized that "the characterization of a transaction for financial accounting purposes, on the one hand, and for tax purposes, on the other, need not necessarily be the same." ${ }^{\text {346 }}$

The second issue addressed by the Court dealt with whether Thor should be entitled to an additional deduction for bad debts. ${ }^{347}$ "During 1965, Thor's new management undertook a stringent review of accounts receivable" ${ }^{348}$ and had determined that an additional deduction for bad debts in the amount of $\$ 136,150$

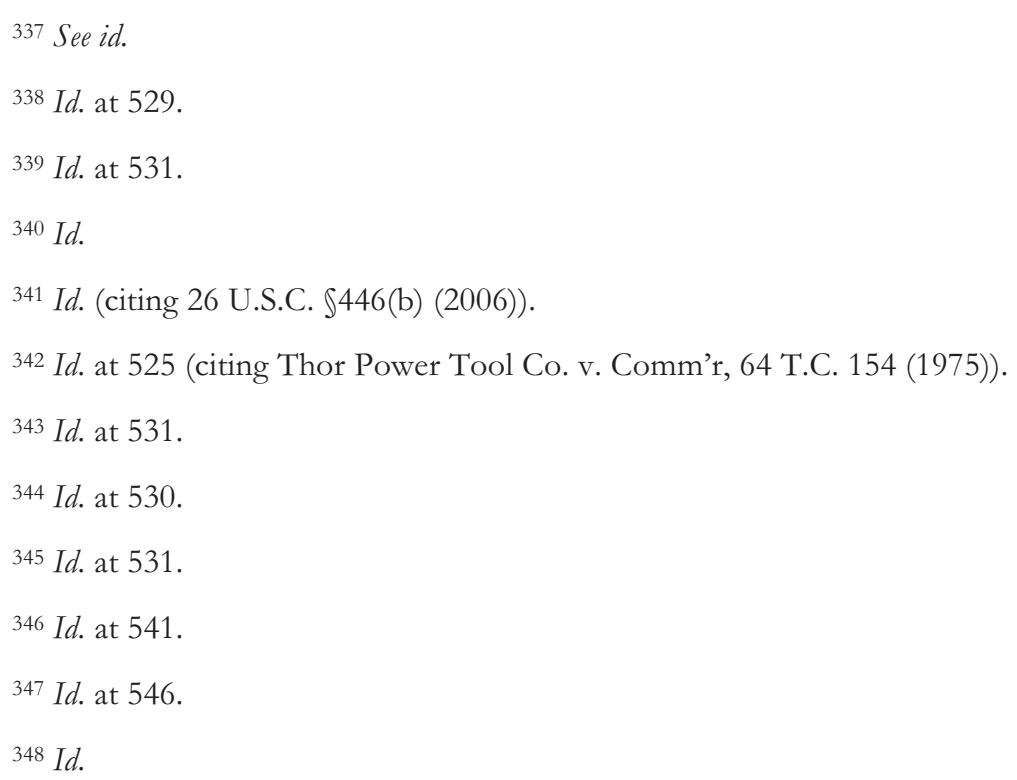


was warranted. ${ }^{349}$ The increased deduction was based on the professional judgment of three levels of Thor's management. ${ }^{350}$ The IRS rejected this deduction claiming the amount was "excessive." 351 According to the IRS, the correct amount of the additional deduction was $\$ 61,359.20 .{ }^{352}$ The IRS determined this amount after examining Thor's average annual chargeoffs ${ }^{353}$ over a six-year period and applying that amount to the outstanding balance of the accounts receivable. ${ }^{354}$

Thor clearly illustrates the IRS's authority to reject GAAP principles whenever the Commissioner believes that the basis of calculating income or expense does not clearly reflect income. Thor further demonstrates that adopting a GAAP method for financial reporting purposes does not ensure its acceptance by regulators or courts outside of a financial reporting context. One can explain the result in Thor from several different perspectives. First, this case stands for the proposition that taxable income and financial income do not need to be determined on the same basis or use the same methodologies. Given the differing objectives between the GAAP and tax structures, it is reasonable to expect that differences will exist. Second, the IRS is charged with the responsibility of protecting the public treasury. As such, in its role as the guardian of the public coffers, the IRS will not permit charges against the U.S. Treasury unless such charges are clear, definite, and determinable. Finally, the taxpayer's failure to dispose of the inventory and its justification for bad debt expenses were fraught with inconsistent actions and unsubstantiated assertions, which invited the only reasonable response from the IRS under these circumstances.

2. Shalala v. Guernsey Memorial Hospital

Shalala v. Guernsey Memorial Hospita ${ }^{\not 55}$ is another case in which the federal government rejected GAAP as the relevant financial standard. The plaintiff, Guernsey Memorial Hospital ("Guernsey"), issued bonds to fund a capital

\footnotetext{
${ }^{349} I d$. at $546-47$.

${ }^{350} I d$. at 546.

${ }^{351} I d$. at 547.

$352 I d$.

353 The term "chargeoff" means recording an expense or charge against income.

${ }^{354}$ Id. at 547 (citing Black Motor Co. v. Comm'r, 41 B.T.A. 300, 302 (1940)).

355 Shalala v. Guernsey Mem'l Hosp., 514 U.S. 87 (1995).
} 
improvements project. ${ }^{356}$ Guernsey refinanced the bonds several years later to take advantage of a change in interest rates. ${ }^{357}$ The refinancing transaction generated "an estimated $\$ 12$ million" dollars in interest expense savings. ${ }^{358}$ However, the refinancing transaction resulted in an "advance refunding or defeasance loss, of $\$ 672,581$." 359 Guernsey sought a reimbursement from Medicare for the loss of approximately $\$ 314,000$. $^{360}$ The amount of the loss was not at issue; however, the timing and the resulting recognition of the loss was. ${ }^{361}$ Guernsey wanted payment of the loss in the year the loss was incurred. ${ }^{362}$ The defendant, the Secretary of Health and Human Services ("HHS"), however, wanted to amortize the loss over the life of the loan. ${ }^{363}$

Guernsey based its reimbursement claim on two regulations ${ }^{364}$ and argued that GAAP controlled the determination. First, Guernsey argued that the applicable regulation allows for reimbursement of reasonable costs provided to program beneficiaries. $^{365}$ Guernsey calculated its reimbursement in accordance with this regulation. ${ }^{360}$ Second, Guernsey argued that the regulations require that

${ }^{356} I d$. at 90 .

357 Id.

${ }^{358} I d$.

359 Id. "The particular costs at issue in this case are known technically as 'advance refunding' or 'defeasance' costs: costs incurred in connection with the refunding of bonded mortgage indebtedness ahead of schedule in order to obtain new financing." Guernsey Mem'l Hosp. v. Sec'y of Health \& Human Servs., 996 F.2d 830, 831 (1993).

360 Shalala, 514 U.S. at 90.

${ }^{361} I d$.

${ }^{362} I d$.

${ }^{363} \mathrm{Id}$.

364 See generally 42 C.F.R. SS 413.20(a), 413.24 (2009). Guernsey "contends that two of these regulations ... mandate reimbursement according to GAAP.” See Shalala, 514 U.S. at 92.

365 Shalala, 514 U.S at 91.

36642 C.F.R. $\int 413.20$ (a) provides:

The principles of cost reimbursement require that providers maintain sufficient financial records and statistical data for proper determination of costs payable under the program. Standardized definitions, accounting, statistics, and reporting practices that are widely accepted in the hospital and related fields are followed. Changes in these practices and systems will not be required in order to 
reimbursements be "based on the accrual basis of accounting." "367 Guernsey argued that the Medicare regulations "mandate reimbursement according to GAAP." HHS disagreed with Guernsey's argument and rejected its claim for reimbursement. ${ }^{369}$ The HHS argued that it is not bound to follow GAAP when determining expense reimbursements. ${ }^{370}$ The HHS forcefully argued that the regulation relied upon by Guernsey "does not bind [it] to reimburse according to GAAP." "371 Instead, the HHS relied upon the Medicare Act, which it maintained:

[A]uthorizes the [HHS] to promulgate regulations "establishing the method or methods to be used" for determining reasonable costs, [and directs it] . . . to "consider, among other things, the principles generally applied by national organizations or established prepayment organizations ... in computing" reimbursement amounts. ${ }^{372}$

Even more startling, the HHS sought to rely upon "an informal Medicare reimbursement guideline," instead of relying on published regulations. ${ }^{373}$ The HHS argued that it was entitled to issue and follow its own informal Medicare reimbursement guideline. ${ }^{374}$ Contrary to the position proposed by Guernsey, the

determine costs payable under the principles of reimbursement. Essentially the methods of determining costs payable under Medicare involve making use of data available from the institution's basis accounts, as usually maintained, to arrive at equitable and proper payment for services to beneficiaries.

367 Shalala, 514 U.S. at 95 . The Supreme Court notes that:

Section 413.24 requires that a provider's cost data be based on the accrual basis of accounting, under which 'revenue is reported in the period when it is earned, regardless of when it is collected, and expenses are reported in the period in which they are incurred, regardless of when they are paid.'

Id.

${ }^{368}$ Id. at 92.

${ }^{369} I d$.

${ }^{370} I d$. at 94.

${ }^{371} I d$.

${ }^{372}$ Id. at $91-92$ (citing 42 U.S.C. $\left.\$ 1395 x(v)(1)(A)(1994)\right)$.

373 Id. at 90 (citing U.S. Dept. of Health \& Human Services, Medicare Provider REIMBURSEMENT MANUAL \ 233 (1993)).

${ }^{374}$ Id. 
HHS reimbursement guideline established the principle that defeasance losses will be amortized over the life of the loan. ${ }^{375}$

The Court considered "whether the Medicare regulations require reimbursement according to generally accepted accounting principles. ${ }^{376}$ In conducting its analysis, the Supreme Court scrutinized the content and the structure of the regulations. ${ }^{377}$ The Supreme Court noted that GAAP is "a beginning point from which the Secretary 'arrive[s] at equitable and proper payment for services." 378 However, GAAP is not the end point. The Supreme Court flatly rejected Guernsey's contention that the relevant GAAP standard, APB $26,{ }^{379}$ controlled the accounting treatment of this transaction. ${ }^{380}$ Instead, the Supreme Court supported the assertion by the HHS that reimbursement occurred under its informal guidance. ${ }^{381}$ The majority noted that "GAAP 'does not necessarily parallel economic reality." 382 The majority added that "[f]inancial accounting is not a science. It addresses many questions as to which the answers are uncertain and is a "process [that] involves continuous judgments and estimates." ${ }^{383}$

The Supreme Court's approach in Shalala raises a number of interesting questions about GAAP's scope, its efficacy, and its persuasive weight before administrative and judicial tribunals. If one reads Shalala narrowly, then one can reasonably conclude that GAAP can be disregarded within the context of a medical

\footnotetext{
$375 \mathrm{Id}$. at 97 . One should note that the approach advocated by HHS is actually consistent with original issue discount principles, which require the amortization of a premium/discount over the life of the original debt. See Financial Accounting Standards Board, Accounting Principles Board OPINION NO. 21 (1971).

376 Shalala, 514 U.S. at 90. There was a second issue that the Court examined, namely, whether the reimbursement guideline that HHS relied upon was "invalid because [it] did not follow the noticeand-comment provisions of the Administrative Procedure Act." Id.

377 "Structure" in this sense means the title, captions, and sequence of the regulations. See id. at 93-94.

${ }^{378}$ Id. at 93.

379 See Financial Accounting Standards Board, Accounting Principles Board Opinion No. 26 (1972).

380 Shalala, 514 U.S. at 95.

381 Id. at 97.

382 Id. at 100.

${ }^{383} \mathrm{Id}$.
} 
reimbursement when the agency has a reimbursement rule. This approach is consistent with the fiscal philosophy of protecting the public treasury and deferring payments. However, if one reads Shalala broadly, then one can likewise reasonably conclude that GAAP can be disregarded anytime a state or federal agency prescribes its own financial standards whether they are cost reimbursement or otherwise.

Unresolved questions abound. Are federal and state agencies required to follow GAAP? Do federal and state agencies have the discretion to craft their own internal policies whenever they relate to budgetary and fiscal matters? Are internal agency guidelines exempt from APA procedures? Shalala raises a gnawing question about the role of GAAP outside of the securities context. Not only did the HHS reject GAAP as the standard of measurement, it replaced it with a measurement standard that was neither "generally accepted" nor subjected to the procedures required by the Administrative Procedure Act. ${ }^{384}$ Shalala is best explained as a demonstration of the vast deference the Supreme Court willingly gives to matters involving economic affairs.

\section{E. Instances of Private Party Reliance on GAAP}

Reliance on GAAP is not limited to matters involving federal or state government. GAAP also influences private party transactions. For example, private parties will frequently use GAAP as a basis to determine their financial rights and obligations, ${ }^{385}$ whether the parties are involved in a corporation, ${ }^{386}$ partnership, joint venture, or an individual context. Similar to public party transactions, however, reliance on GAAP in private party transactions may not ensure the intended result.

384 Id. at 90.

385 See LSB Int'l, Inc., v. Mohawk Valley Ranch, Inc., Nos. C034937, 2001 WL 1243955, at*1 (Cal. Dist. Ct. App. Oct. 18, 2001) (describing a partnership dissolution case). In the instant case, "Article IX, paragraph (B) [of the partnership agreement] provides generally that 'net profits and net losses ... shall be determined in accordance with generally accepted accounting principles . . in the same manner as the net income or net loss . . is determined for federal income tax purposes." Id. at *2.

386 See Schulenberg v. River Hills Invs., Inc., No. 90-0637, 1990 WL 262065, at *1 (Wis. Ct. App. Dec. 18, 1990). Schulenberg involved a common stock buyout agreement that used GAAP as a reference for valuation purposes. "The formula in this buy-sell agreement set the common stock value at book value, as determined by generally accepted accounting principles (GAAP)." Id. at *1. The Supreme Court of Wisconsin amended WIS. STAT. S (Rule) 809.23(3) to provide that unpublished opinions issued on or after July 1, 2009 "may be cited for their persuasive value." See Wis. Sup. Ct., Rule Order No. 08-02, Jan. 6, 2009, available at http://www.wicourts.gov/sc/rulhear/DisplayDocument. html? content $=$ html\&seqNo $=35116$. 


\section{Bolt v. Merrimack Pharmaceuticals}

In Bolt v. Merrimack Pharmaceuticals ("Bolt"), ${ }^{387}$ the court was asked to resolve the meaning of the term, "net worth" within the context of a disputed redemption transaction. ${ }^{388}$ Neither the company's articles of organization, nor GAAP defined the meaning of the term "net worth." 389

The plaintiff, Albert Bolt ("Bolt"), owned "52,488 shares of Series A Redeemable Preferred Stock" in the defendant company, Merrimack Pharmaceuticals, Inc. ("Merrimack"). ${ }^{390}$ Bolt sought to redeem his stock in accordance with the terms of the company's articles of organization, which provided that a shareholder could redeem his stock anytime the "net worth of the Corporation, determined in accordance with ... [GAAP] ..., equals or exceeds five million dollars." ${ }^{\text {391 }}$ Merrimack, however, resisted the attempt to redeem the stock. ${ }^{392}$ Merrimack argued that the redemption provisions implicitly contemplated that the redeemable preferred stock would be characterized as debt and therefore treated as a liability. ${ }^{393}$ Merrimack thus maintained that the financial threshold requiring redemption of the stock had not been reached. ${ }^{394}$ Bolt disagreed and argued that the redeemable preferred stock is properly characterized as equity, not debt. ${ }^{395}$

387 Bolt v. Merrimack Pharm., Inc., 503 F.3d 913 (9th Cir. 2007).

388 Id. at 915-16. "Preferred stock sometimes represents a permanent commitment of capital to a corporation and sometimes does not . . The right to require redemption may be held by the stockholder, by the corporation, or by both." JEFFREY D. BAUMAN ET AL., CORPORATIONS LAW AND POLICY 242-43 (2003).

389 Bolt, 503 F.3d at 916.

${ }^{390} I d$. at 914.

391 Id ("At any time from and after December 31, 1997, if the net worth of the Corporation, determined in accordance with generally accepted accounting principles and as shown on the balance sheet of the Corporation as of the end of the fiscal quarter then most recently ended, equals or exceeds five million dollars $(\$ 5,000,000.00)$, then upon the request of the holder of [the Series A] Preferred Stock, the Corporation shall redeem at the Redemption Price any and all shares of [the Series A] Preferred Stock which such holder, by such request, offers to the Corporation for redemption.").

392 Id. at 915.

${ }^{393} \mathrm{Id}$. at 918.

394 Id. at 916.

${ }^{395} \mathrm{Id}$. at 917. 
Bolt initiated a lawsuit seeking a declaration that the company's "net worth" exceeded the five million dollar threshold after repeated requests to Merrimack to redeem his preferred stock proved unsuccessful. ${ }^{396}$ The district court held that the company's net worth, in fact, exceeded the five million dollar threshold. ${ }^{397}$ The Ninth Circuit affirmed. ${ }^{398}$

This case demonstrates the various approaches and the range of authorities that a court may encounter when resolving questions concerning GAAP. The court in Bolt examined the relevant regulations and three varying levels of accounting pronouncements before making a decision. First, the court examined the applicability of Regulation S-X. ${ }^{399}$ Merrimack argued that Regulation S-X required treating the preferred stock as a liability and not as equity. ${ }^{400}$ Merrimack relied on language dictating the physical placement of the preferred stock on the balance sheet in support of his position. ${ }^{401}$ Specifically, Merrimack argued that since Regulation S-X required placing the preferred stock "outside" the equity section that "it should [therefore,] be considered akin to a liability for purposes of determining net worth." ${ }^{402}$ The court, however, rejected Merrimack's interpretation of Regulation S$\mathrm{X}^{403}$

Second, the court examined Accounting Standards No. 150 (“AS 150"). ${ }^{404}$ Although AS 150 was not in effect at the time of the disputed transaction, the court nonetheless considered it in its analysis, because it "believe[d] that this statement offers helpful guidance that confirms [its] conclusion." ${ }^{405}$ After reviewing AS 150,

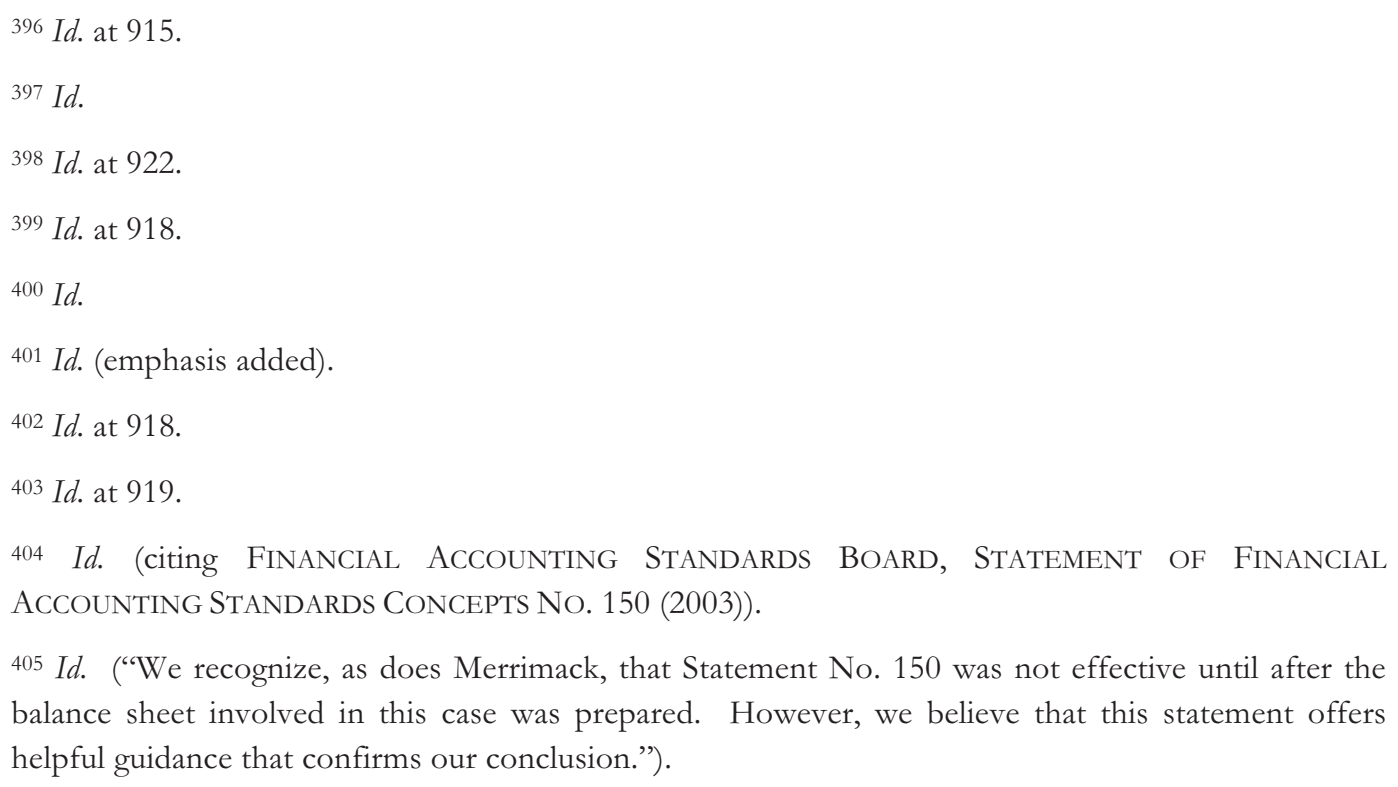
helpful guidance that confirms our conclusion.”). 
the court then rejected it as a source of authority. ${ }^{406}$ The court reasoned that AS 150 was not applicable to the transaction at hand, because AS 150 deals with unconditional events while the present case deals with a conditional event. ${ }^{407}$

Third, the court examined FASB Concept No. $6 .^{408}$ The court stated that "we do not believe [that] the conceptual definitions found therein require a conclusion that the Series B Stock must be classified as part of total liabilities." 409 The court noted that:

Concept No. 6 defines "liabilities" as "probable future sacrifices of economic benefits arising from present obligations of a particular entity to transfer assets or provide services to other entities in the future as a result of past transactions or events," . . . and [defines] "equity" as "the residual interest in the assets of an entity that remains after deducting its liabilities. ${ }^{410}$

What is striking is the court and the litigants failed to take note of the declaration by FASB that " $[\mathrm{u}]$ nlike a Statement of Financial Accounting Standards, a Statement of

406 Id.

407 Id. The court noted that:

Statement No. 150 requires that a mandatorily redeemable financial instrument, defined as a financial instrument that "embodies an unconditional obligation requiring the issuer to redeem the instrument by transferring its assets at a specified or determinable date (or dates) or upon an event certain to occur," be reclassified as a liability.

Id. (emphasis in original). The court further stated:

Even if Statement No. 150 applied in this case, the parties agree that it would not require the Series B Stock to be classified as a liability because redemption of that stock is conditional and expressly beyond the statement's scope. A redeemable preferred stock conditioned "upon an event not certain to occur becomes mandatorily redeemable — and, therefore, becomes a liability — if that event occurs, the condition is resolved, or the event becomes certain to occur."

Id.

$408 I d$. at 920.

${ }^{409} I d$.

${ }^{410} I d$. (internal citations omitted). 
Financial Accounting Concepts does not establish generally accepted accounting principles. $" 411$

In the court's final analysis, it used two lines of reasoning to resolve the meaning of "net worth." First, the court considered the common and ordinary meaning of the term "net worth." ${ }^{\prime 12}$ In this part of the analysis, the court rejected the narrower reading advanced by Merrimack and opted for the common and ordinary meaning of the word. ${ }^{413}$ Second, the court simply deferred to the determination made by the independent auditors "that Merrimack's balance sheet 'presents fairly ... the financial position of Merrimack . . . in conformity with accounting principles generally accepted"' and held for Bolt. ${ }^{414}$

In addition to consulting the traditional case law, statutes, and administrative resources, courts dealing with accounting issues must also consult a vast array of GAAP standards that are pliable, complex, and confusing. As these cases illustrate, courts must discern among the differing levels of GAAP and evaluate the conflicting interpretations of GAAP before deciding whether to accept or reject GAAP as a source of authority. The final result is not always clear or consistent. The challenge is further exacerbated by the lack of certainty and guidance as courts apply GAAP standards that are perceived by professionals in varying degrees as aspirational, discretionary, or prescriptive.

\section{CONCLUSION}

This article proposes that a federal agency (either a reformed SEC or a newly created agency) take an active and primary role in establishing accounting standards. ${ }^{415}$ Given the pervasive nature of accounting standards, their influence on

\footnotetext{
411 See Financial Accounting Standards Board, Statement of Financial Accounting STANDARDS CONCEPTS NO. 1, at 6 (1978).

412 Bolt, 503 F.3d at 916.

${ }^{413} I d$.

${ }^{414} I d$. at 921.

415 As one source explains:
}

One potential argument against a government ... agency is the potential for inefficiency, a common criticism of government institutions. This argument loses its potency when one puts it in perspective. Financial statement restatements over the five-year period between 1997 and 2002 cost financial markets approximately $\$ 100$ billion in market capitalization. It's unlikely that even the most inefficient 
U.S. economic policy, and their relevance to the substantive rights of individuals, requiring the SEC (or a newly created federal agency) to take an active and primary role in creating accounting standards is both reasonable and responsible. ${ }^{416}$ Private sector observations, however, should be encouraged.

Transparency, disclosure, and confidence building - the stated objectives of SEC policy - are substantially compromised when third party standard setters are involved. The government's act of delegating standard setting responsibility to an organization with no meaningful public duty is imprudent and irresponsible and will predictably contribute to another collapse of the markets, as accountants and management conceive new ways to circumnavigate rules shrouded with the veil of ambiguity and discretion.

To be effective, rules should enable predictive behavior, provide certainty, assist with compliance and enforcement efforts, and not be unduly burdensome or repressive. These elements invariably make effective jurisprudence. In contrast, rules that tolerate extreme ranges in behavior are counterproductive, self-destructive, and of limited social utility. History has demonstrated that a repressive and interventionist structure is inevitably doomed to failure. ${ }^{417}$ Similarly, a

government agency would lose $\$ 100$ billion over a five-year period.

Denis A. Klimentchenko, Myth of Auditor Independence, 2009 U. ILL. L. REV. 1275, 1299 (2009).

416 Koenig, supra note 16, at 1037-38 ("Although mandatory disclosure seems to be a means of generating vital market information, many commentators argue that securities laws, like disclosure rules, produce few benefits and considerable costs. Specifically, under the free market for information theory, regulation is costly and unnecessary because corporate managers, seeking to maximize shareholder value, will release information voluntarily up to the point that the marginal benefits of disclosure equal the marginal costs. Because market participants desire information to make investment decisions and "assume the worst" in the absence of released information, a company that wishes to raise capital through public markets has an incentive to and can profit by providing voluntary disclosures.").

417 See Vincent J. Samar, Can a Constitutional Amendment be Unconstitutional?, 33 OKLA. CiTY U. L. REV. 667, 685 n.55 (2008) ("The failure of Prohibition has been admitted by many of its own supporters. In a 1932 letter, the wealthy industrialist John D. Rockefeller, Jr., stated that '[w] hen Prohibition was introduced, I hoped that it would be widely supported by public opinion and the day would soon come when the evil effects of alcohol would be recognized. I have slowly and reluctantly come to believe that this has not been the result. Instead, drinking has generally increased; the speakeasy has replaced the saloon; a vast army of lawbreakers has appeared; many of our best citizens have openly ignored Prohibition; respect for the law has been greatly lessened; and crime has increased to a level never seen before.”). 
noninterventionist policy invites adversity as participants will predictably seek to maximize their gains and externalize all possible costs.

The process of creating accounting standards is in need of reform. Accounting standards, called GAAP or any successive nomenclature, ${ }^{418}$ must be clear, consistent, conservative, ${ }^{419}$ uniform, and expected and understood by the average investor. Accounting standards must be oriented to benefit shareholder disclosure to allow for reasonably prudent and meaningful investor decisions. Accounting standards should not be oriented to facilitate management discretion or self-interest. Any new, emerging, or extraordinary method of measurement that is inconsistent with how an average investor reasonably expects information to be reported must be fully disclosed setting forth the rationale for the use of the method, the projected benefits of the proposal, and the risks associated with the method.

Financial statement reporting, under any system, will have inherent limitations. The goal of a reporting system should be to create a system that reflects the reasonable expectations of the user. ${ }^{420}$ Perhaps then, the accounting profession can begin to reduce the dissonance created by the competing interests of shareholders, management, and its members; arrive at a reporting system that is faithful to the underlying economics; and stop the game of nods and winks. ${ }^{421}$

\footnotetext{
418 A possible successive standard such as IFRS.

419 Conservatism is the hallmark of financial reporting. "There is a place for a convention such as conservatism-meaning prudence-in financial accounting and reporting, because business and economic activities are surrounded by uncertainty." FINANCIAL ACCOUNTING STANDARDS BOARD,

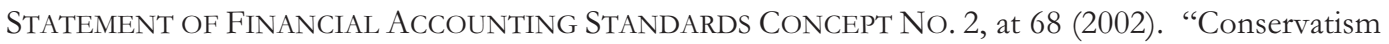
is a prudent reaction to uncertainty to try to ensure that uncertainties and risks inherent in business situations are adequately considered." Id. at 69.

${ }^{420}$ For example, accounting standards could be gauged from the point of view of the contracting counterparty. In this regard, revenues and expenses would only be recorded if the contracting counterparty hypothetically recognizes and agrees that there exists an enforceable right and a resulting performance obligation.

${ }^{421}$ Levitt, supra note 77 ("Representational faithfulness is correspondence or agreement between a measure or description and the phenomenon it purports to represent. In accounting, the phenomena to be represented are economic resources and obligations and the transactions and events that change those resources and obligations.").
} 